Part of Journal of Research of the National Bureau of Standards, Volume 19, September 1937

\title{
EXTRACTION OF JERUSALEM-ARTICHOKE JUICES IN AN EXPERIMENTAL DIFFUSION BATTERY
}

\author{
Max J. Proffitt, John A. Bogan, and Richard F. Jackson
}

\section{ABSTRACT}

In 12 experiments on the extraction of polysaccharides from jerusalem-artichoke tubers, conducted in a column having an average length of 17.75 cells, set up in the miniature diffusion battery described in a previous paper, ${ }^{1}$ the mean charge was $1.05 \mathrm{~kg}$ of cossettes occupying 51.8 percent of the cell space at a density of filling of $34.6 \mathrm{lb} / \mathrm{ft}^{3}$ The volume of the accompanying flood liquid was $915 \mathrm{ml}$, and the velocity of the flux was 2.85 percent of the column length per minute in a period of 5 minutes, resulting in a rate of extraction of $0.764 \mathrm{~g} / \mathrm{min} / \mathrm{m}^{2}$ of cossette surface calculated as reducing sugars, of which 76.7 percent was levulose. In eight experiments the yield of pulp was $100.5 \mathrm{~g} / 100 \mathrm{~g}$ of cossettes and the production of pulp water was $85.4 \mathrm{~g} / 100 \mathrm{~g}$ of cossettes. In three experiments the yield of pressed pulp was 45.1 percent, and of dried pulp 4.3 percent of the weight of wet pulp. The polysaccharides containing the higher proportions of levulose apparently diffuse at least as rapidly as those containing smaller proportions of levulose. Attenuation gradients for three columns supply data for a future study of the kinetics of the process.

\section{CONTENTS}

I. Introduction

II. Experimental procedure $\ldots \ldots$

1. Setting up the material column

2. Duration of experiments_......... 264

3. Ending the run

4. Sampling of material column

(a) Method of sampling

(b) Results of column sampling

5. Temperature maintenance and rates of heat losses ...... 269

6. Temperature schedules . . .

7. Working volumes_........ 271

III. Typical extraction data

1. Gross rates of extraction

2. Residues $\ldots \ldots$

IV. Special regimes_...

1. Extraction with preheating

2. Midcolumn dosage with sulphur dioxide $\ldots \ldots$

(a) Experimental conditions _................... 281

(1) Experiment of May $7,1928 \ldots$

(b) Experimental results

(c) Relative extractions of sulphur dioxide...... 283

V. Summary

\section{INTRODUCTION}

The present paper is a report on some of the experimental results obtained in the extraction of polysaccharides from cossettes prepared from jerusalem articbokes ${ }^{2}$ in the battery previously described. ${ }^{3}$ All

1 J. Research NBS 15, 441 (1935) R P840; Ind. Eng. Chem. 27, 1266 (1935).

2 J. Research NBS 17, 615 (1936) RP931.

3 J. Research NBS 15, 441 (1935) RP840; Ind. Eng. Chem. 27, 1266 (1935). 
of the experiments, except those relating to reagent dosage, were carried out in the single-row arrangement of the cells, as illustrated in figure 1. Terms defined in either of the previous papers will be used as convenient in the present discussion without further definition.

\section{EXPERIMENTAL PROCEDURE}

\section{SETTING UP THE MATERIAL COLUMN}

Generally the battery was started early in the morning. First, the whole battery was heated by filling all of the cells with hot water and then passing hot water fluxwise through the filled cells, while maintaining appropriate pressures of steam on the calorisators. The water was emptied from each cell just previous to the introduction of the cell's first charge of cossettes, and the first charges were usually introduced to the successive cells at intervals of time equal to the charging period, ${ }^{4}$ which already had been chosen for the run as a whole. The first cell set-up was primed with hot water, all others with the liquid efflux from the cell next previously set up. In most of the runs the drawing of diffusion juice was begun when about half of the cells in the column were filled; in a few runs, later. Obviously, the first charge from which juice was drawn was the first to receive the full amount of flux for the term of processing. In all previous charges the element of flood recession ${ }^{5}$ had been missing from the flux for a duration of from one to several periods. When in addition these charges had been set up more rapidly than the headway selected for the run as a whole, they finally received a total duration of treatment which was less than the standard term of retention for that run. This resulted in somewhat greater rejectment of polysaccharides in the residues for the first round of the battery than for the subsequent rounds in that run.

Once the drawing had been started, the regular periodic procedure was: (1) In most experiments, first to draw from the newly entered charge; then to prime the next charge. In other experiments the procedure was either (2) to prime ahead of drawing, or (3) to draw the last charge and prime the one next to it simultaneously. In the second procedure each charge was left standing in the flooded condition for more than half a period before it was entered into the column; in the first and third procedures it was entered into the column immediately after the flooding was complete.

\section{DURATION OF EXPERIMENTS}

Each experiment was continued until a state of apparently steady performance had been attained for a duration of at least one term. Thus it was assumed that the condition of the extraction column had represented a state of coordination or poise among the particular regime of operation, the resulting process, and the associated condition of the material under treatment, for a time at least as long as the term that the cossettes were retained in the process. The minimum acceptable duration for an experiment on this basis would seem to be about four terms. Most of them exceeded this, as indicated in the column headed "Number of column lengths worked" in table 7.

4 J. Research NBS 15, 444 (1935) RP840; Ind. Eng. Chem. 27, 1268 (1935).

$5 \mathrm{~J}$. Research NBS 15, 446 (1935) RP840; Ind. Eng. Chem. 27, 1268 (1935). 


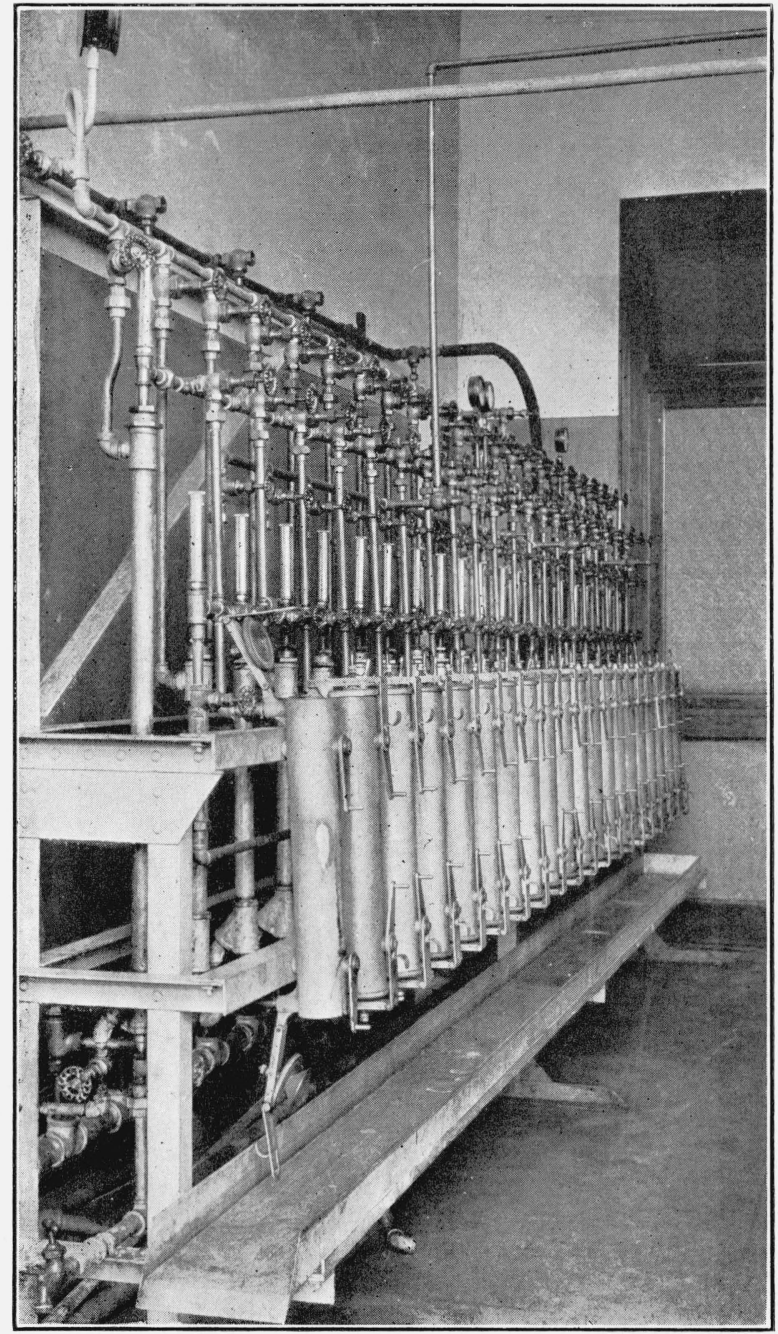

FIGURE 1.-Miniature battery with cells arranged in straight row.

The structure and equipment of the battery in both the straight and folded-row arrangements have been described in detail in a previous paper (R P840). 


\section{ENDING THE RUN}

The experiments were terminated in two ways: generally by "sweetening off", occasionally by "dropping" the whole material column at once for the purpose of "column sampling." The sweetening off was accomplished in a manner approximating commercial practice, except that in shortening the column, cells were dropped out of service only after they had served as the water inlet while the estimated average efflux weight of extract was being drawn into the draft receiver, rather than while the draft quantity only was being removed. When the concentration of reducing sugars in the extract had fallen to 1 percent or less, the operations were terminated and the remaining charges were discarded as residues. This condition was usually attained when the material column had been shortened by slightly less than half its regular operating length for that experiment. Table 1 compares the output performances attained in several experiments during regular operation and during the sweetening off.

TABLE 1.-Comparison of output performance during sweetening off with that accomplished during regular operation in several experiments

\begin{tabular}{|c|c|c|c|c|}
\hline \multirow[b]{2}{*}{1925} & \multirow[b]{2}{*}{ Product } & \multirow{2}{*}{$\begin{array}{l}\text { Reducing sugars } \\
\text { expressed as- }\end{array}$} & \multicolumn{2}{|c|}{ Average for- } \\
\hline & & & $\begin{array}{l}\text { Regular } \\
\text { regime }\end{array}$ & $\begin{array}{l}\text { Sweeten- } \\
\text { ing off }\end{array}$ \\
\hline $\begin{array}{cl}\text { July } & 9 \\
9 & \\
9 & 9\end{array}$ & $\begin{array}{l}\text { Diffusion juice... } \\
\text { Pulp sap_....... } \\
\text { Pulp water }\end{array}$ & $\begin{array}{l}\text { Percentage } \\
\mathrm{g} / 100 \mathrm{ml} \\
\mathrm{g} / 100 \mathrm{ml}\end{array}$ & $\begin{array}{l}9.08 \\
0.312 \\
.055\end{array}$ & $\begin{array}{l}4.48 \\
0.450 \\
.238\end{array}$ \\
\hline $\begin{array}{l}13 \ldots \\
13 \ldots \\
13 \ldots\end{array}$ & $\begin{array}{l}\text { Diffusion juice... } \\
\text { Pulp sap. } \\
\text { Pulp water }\end{array}$ & $\begin{array}{l}\text { Percentage } \\
\mathrm{g} / 100 \mathrm{ml} \\
\mathrm{g} / 100 \mathrm{ml}\end{array}$ & $\begin{array}{r}10.03 \\
0.313 \\
.080\end{array}$ & $\begin{array}{l}5.74 \\
0.357 \\
.187\end{array}$ \\
\hline 16 & Diffusion juice _. & Percentage & 9.13 & 5. 88 \\
\hline $\begin{array}{l}24 \\
24\end{array}$ & $\begin{array}{l}\text { Pulp sap_..... } \\
\text { Pulp water..- }\end{array}$ & $\begin{array}{l}\mathrm{g} / 100 \mathrm{ml} \\
\mathrm{g} / 100 \mathrm{ml}\end{array}$ & $\begin{array}{r}0.355 \\
.081\end{array}$ & $\begin{array}{r}0.708 \\
.212\end{array}$ \\
\hline $\begin{array}{l}30_{\ldots} \\
30_{-}\end{array}$ & $\begin{array}{l}\text { Pulp sap } \\
\text { Pulp water.... }\end{array}$ & $\begin{array}{l}\mathrm{g} / 100 \mathrm{ml} \\
\mathrm{g} / 100 \mathrm{ml}\end{array}$ & $\begin{array}{l}.326 \\
.095\end{array}$ & $\begin{array}{l}.584 \\
.309\end{array}$ \\
\hline A verage & $\left\{\begin{array}{l}\text { Diffusion juice } \\
\text { Pulp sap_ater } \\
\text { Pulp wate }\end{array}\right.$ & $\begin{array}{l}\text { Percentage } \\
\mathrm{g} / 100 \mathrm{ml} \\
\mathrm{g} / 100 \mathrm{ml}\end{array}$ & $\begin{array}{l}9.43 \\
0.327 \\
.078\end{array}$ & $\begin{array}{l}5.37 \\
0.545 \\
.239\end{array}$ \\
\hline
\end{tabular}

\section{SAMPLING OF MATERIAL COLUMN}

In order to study the mode of the performance of an extraction process of this type it is necessary to know the residual concentrations existing in the sap of the particles and in the associated flood liquid at several levels ${ }^{6}$ along the column at a particular instant whose relation to a period is known. The necessary observations require the withdrawal of samples of a size which would destroy the working characteristics of a column so small as any of those studied. For this reason column sampling has been accomplished only by suddenly discharging the whole contents of the battery without previous disturbance of the prevailing regular operation. Each sample comprises the whole contents of a cell, separated immediately into two parts, the chips and the flood liquid. ${ }^{7}$ Since each part represents the respective mean for the whole cell, which is a considerable section of the column,

6 J. Research NBS 15, 446 (1935) R P840; Ind. Eng. Chem. 27, 1268 (1935).

7 J. Research NBS 15, 458 (1935) R P840; Ind. Eng. Chem. 27, 1273 (1935). 
the concentrations are assumed to represent the existing conditions at the center of the cell. Thus to obtain results which can be interpreted with precision, it is necessary to sample several cells and preferable to sample them all. Moreover, the sampling must be completed within an interval of time which is short enough to be considered practically instantaneous.

\section{(a) METHOD OF SAMPLING}

When the operation of the column is about to be terminated, several experienced operators are stationed at even intervals along its length and a sample receiver is placed under each cell to be sampled. Precisely at the instant planned, the water input to the column is stopped and the whole contents of each cell are dumped into the tray of its respective receiver. The operations are performed as rapidly as possible and as nearly simultaneously as the several operators can act. Each receiver with its contents is weighed during the 5-minute interval allowed for draining. At the end of this interval the trays are removed, their contents transferred to individual closed containers, and each bucket with its contents of flood liquid is weighed. The pressed-out cossette sap and the flood liquid from each sample are analyzed separately. ${ }^{8}$ For the present purpose the rapid method ${ }^{9}$ is not recommended, although it may be used for samples taken near the head of the column.

\section{(b) RESULTS OF COLUMN SAMPLING}

The concentrations observed in three columns of material which were sampled and tested as specified above are presented in table 2 . The listed concentrations are those observed in the prepared samples at $20^{\circ} \mathrm{C}$; they require correction for the conditions of temperature as they existed in the material under operation. For the two July experiments included in this group, the temperatures observed at 15-minute intervals in the flood liquid issuing from each posture were recorded. The means of these observations for the respective whole runs are included in table 6 . The temperatures observed during an interval of time coinciding approximately with the duration of retention of the "oldest" cossettes in the respective columns at the instant of sampling are presented in tables 3 and 4 . The lines and arrows in each table indicate the progressive conditions of temperature for this "oldest" charge during the major portion of its life history and the last column of figures in each table indicates the mean of all the observations taken for each posture during the time that this charge was actually in process. Comparison of these two columns respectively with items 10 and 11 of table 6 reveals that the mean temperatures for this interval in each case were similar to the means for the run as a whole. The temperature control in the April experiment was not very different.

8 BS J. Research 9, 604 (1932) RP495.

- BS J. Research 9, 697 (1932) R P495. 


\section{TABLE 2.-Attenuation gradients of sampled columns}

Observed concentrations of reducing sugars in cossette input and diffusion juice output, in percent by weight; and in residue output and in cell contents of sap and flood liquid under processing, stated in $\mathrm{g} / 100$ $\mathrm{ml}$ at room temperature. The (apparent) head is the difference between the sap and flood liquid concentrations during processing.

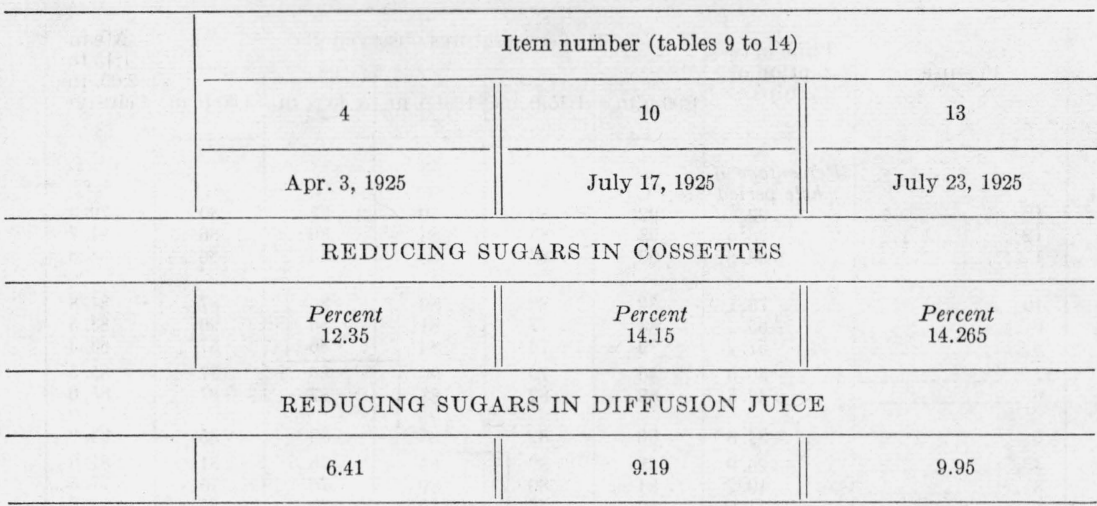

REDUCING SUGARS IN CELL CONTENTS

\begin{tabular}{|c|c|c|c|c|c|c|c|c|c|}
\hline \multirow{2}{*}{ In posture no. } & \multicolumn{3}{|c|}{ At start } & \multicolumn{3}{|c|}{ At end } & \multicolumn{3}{|c|}{ At start } \\
\hline & Sap & Flood & Head & Sap & Flood & Head & Sap & Flood & Head \\
\hline 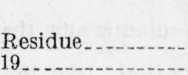 & $\begin{array}{c}g / 100 \mathrm{ml} \\
10.665\end{array}$ & $\begin{array}{r}g / 100 \mathrm{ml} \\
10.143\end{array}$ & $\begin{array}{c}g / 100 \mathrm{ml} \\
10.522 \\
0\end{array}$ & $\begin{array}{c}g / 100 m l \\
20.597\end{array}$ & $\begin{array}{c}g / 100 m l \\
20.314 \\
2\end{array}$ & $\begin{array}{c}g / 100 \mathrm{ml} \\
20.283\end{array}$ & $\begin{array}{r}g / 100 \mathrm{ml} \\
10.365 \\
.522\end{array}$ & $\begin{array}{r}g / 100 \mathrm{ml} \\
10.104 \\
.180\end{array}$ & $\begin{array}{r}g / 100 \mathrm{ml} \\
10.261 \\
.342\end{array}$ \\
\hline 18 & $\begin{array}{l}\text { 1. } 150 \\
1.322 \\
1.951\end{array}$ & $\begin{array}{r}.578 \\
.967 \\
1.464\end{array}$ & $\begin{array}{l}.572 \\
.355 \\
.487\end{array}$ & - & & & 1. 167 & .878 & .289 \\
\hline $\begin{array}{l}15 \\
14 \\
13 \\
12 \\
11\end{array}$ & $\begin{array}{l}2.565 \\
3.340 \\
4.079 \\
\text { 4. } 880 \\
5.760\end{array}$ & $\begin{array}{l}2.141 \\
2.892 \\
3.625 \\
4.562 \\
5.210\end{array}$ & $\begin{array}{l}.424 \\
.448 \\
.454 \\
.318 \\
.550\end{array}$ & .597 & .314 & .283 & 2.478 & $\begin{array}{r}2.250 \\
-\end{array}$ & 228 \\
\hline $\begin{array}{l}10 \\
9 \\
8 \\
8 \\
6\end{array}$ & $\begin{array}{l}6.521 \\
7.542 \\
8.60 \\
9.72 \\
10.81\end{array}$ & $\begin{array}{r}6.040 \\
7.240 \\
8.22 \\
9.34 \\
10.75\end{array}$ & $\begin{array}{l}.481 \\
.302 \\
.38 \\
.38 \\
06\end{array}$ & \begin{tabular}{c}
2.08 \\
\hdashline 3.68 \\
\hdashline
\end{tabular} & \begin{tabular}{c}
1.57 \\
\hdashline $2.77^{--}$ \\
\hdashline-10
\end{tabular} & $\begin{array}{c}.51 \\
.91 \\
-.-1 \\
-.9\end{array}$ & 5.136 & $\begin{array}{c}4.76 \\
7.79\end{array}$ & .376 \\
\hline $6 \ldots \ldots \ldots$ & 10.81 & 10.75 & .06 & - & $-\ldots$ & $-\cdots$ & 8.60 & 7. 72 & .88 \\
\hline 5. 2 & $\begin{array}{l}12.15 \\
13.05\end{array}$ & $\begin{array}{l}11.46 \\
11.99\end{array}$ & $\begin{array}{r}.69 \\
1.06\end{array}$ & 6.91 & 5.53 & 1.38 & & & \\
\hline $\begin{array}{l}3 \\
2 \\
2\end{array}$ & $\begin{array}{l}13.17 \\
13.68\end{array}$ & $\begin{array}{l}11.25 \\
10.72\end{array}$ & $\begin{array}{l}1.92 \\
2.96\end{array}$ & 11. 45 & 9.25 & 2.20 & 12.91 & 12.14 & .77 \\
\hline 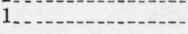 & 12.46 & 10.35 & 2.11 & 12.68 & 9.21 & 3.47 & 13.84 & 9.81 & 4.03 \\
\hline
\end{tabular}

1 Since these columns were sampled at the start of a period, the concentrations in the $n$th cell do not represent the final pulp and pulp water. The concentrations which would have existed at the end of the period had the process continued, are assumed to be equal to the means for the previously sampled residues.

2 Since this column was sampled at the end of a period, the concentrations observed in the $n$th cell at the time of dropping the column are assumed to represent the condition of the material (at $20^{\circ} \mathrm{C}$ ). 
TABLE 3.-Record of the temperatures observed at 15-minute intervals during approximately the time of retention of the particular charge of cossettes which at the time of sampling was situated in posture 13 of the material column in the experiment of July 17, 1925

\begin{tabular}{|c|c|c|c|c|c|c|c|}
\hline \multirow{2}{*}{ Posture } & \multirow{2}{*}{$\begin{array}{l}\text { Time of re- } \\
\text { tention of } \\
\text { chips }\end{array}$} & \multicolumn{5}{|c|}{ Temperatures observed at- } & \multirow{2}{*}{$\begin{array}{l}\text { Mean } \\
1: 15 \text { to } \\
2: 00 \text {, in } \\
\text { clusive }\end{array}$} \\
\hline & & 1:00 p.m. ${ }^{\mathrm{s}}$ & 1:15 p. m. & 1:30 p. m. & 1:45 p.m. & 2:00 p. m. & \\
\hline $\begin{array}{l}13 \\
12 \\
11\end{array}$ & $\begin{array}{c}\text { Percentage of } \\
\text { whole period } \\
92.6 \\
88.5 \\
80.8\end{array}$ & $\begin{array}{l}{ }^{\circ} \mathrm{C} \\
92 \\
93 \\
90\end{array}$ & $\begin{array}{l}{ }^{\circ} \mathrm{C} \\
80 \\
83 \\
83\end{array}$ & $\begin{array}{l}{ }^{\circ} \mathrm{C} \\
80 \\
84 \\
85\end{array}$ & $\begin{array}{l}{ }^{\circ} \mathrm{C} \\
77 \\
80 \\
85\end{array}$ & $\begin{array}{l}{ }^{\circ} \mathrm{C} \\
80 \\
80 \\
86\end{array}$ & $\begin{array}{l}{ }^{\circ} \mathrm{C} \\
79.3 \\
81.7 \\
84.8\end{array}$ \\
\hline $\begin{array}{l}10 \\
9 \\
8\end{array}$ & $\begin{array}{l}73.1 \\
65.4 \\
57.7\end{array}$ & $\begin{array}{l}82 \\
83 \\
79\end{array}$ & $\begin{array}{l}80 \\
77 \\
76\end{array}$ & $\begin{array}{l}80 \\
81 \\
84\end{array}$ & $\begin{array}{l}86 \\
86 \\
86\end{array}$ & $\begin{array}{l}87 \\
90 \\
87\end{array}$ & $\begin{array}{l}84.8 \\
83.5 \\
83.3\end{array}$ \\
\hline 7 & $\begin{array}{l}50.0 \\
42.3\end{array}$ & $\begin{array}{l}80 \\
88\end{array}$ & $\begin{array}{l}79 \\
82\end{array}$ & $\begin{array}{l}90 \\
84\end{array}$ & $\begin{array}{l}86 \\
87\end{array}$ & $\begin{array}{l}87 \\
87\end{array}$ & $\begin{array}{l}85.5 \\
85.0\end{array}$ \\
\hline 5 & 34.6 & 90 & 82 & 83 & 83 & 85 & 83.2 \\
\hline 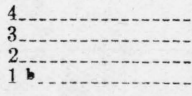 & $\begin{array}{r}26.9 \\
19.2 \\
11.5 \\
3.8\end{array}$ & $\begin{array}{l}88 \\
84 \\
80 \\
78\end{array}$ & $\begin{array}{l}82 \\
80 \\
72 \\
72 \\
\end{array}$ & $\begin{array}{l}85 \\
80 \\
80 \\
78\end{array}$ & $\begin{array}{l}76 \\
75 \\
75 \\
72\end{array}$ & $\begin{array}{l}81 \\
75 \\
65 \\
50\end{array}$ & $\begin{array}{l}81.0 \\
77.5 \\
73.0 \\
68.0\end{array}$ \\
\hline $\begin{array}{l}\text { Means: } \\
13 \text { to } 4 \\
13 \text { to } 3 \\
13 \text { to } 1\end{array}$ & $\begin{array}{l}92.6 \text { to } 26.9 \\
92.6 \text { to } 19.2 \\
92.6 \text { to } 3.8\end{array}$ & $\begin{array}{l}86.5 \\
86.3 \\
85.2\end{array}$ & $\begin{array}{l}80.4 \\
80.4 \\
79.1\end{array}$ & $\begin{array}{l}83.6 \\
83.3 \\
82.6\end{array}$ & $\begin{array}{l}83.2 \\
82.5 \\
81.1\end{array}$ & $\begin{array}{l}85.0 \\
84.1 \\
80.0\end{array}$ & $\begin{array}{l}83.1 \\
82.5 \\
80.7\end{array}$ \\
\hline
\end{tabular}

- Temperatures of column 15 minutes before chips in posture 13 at time of sampling were introduced into column; not included in means listed in last column of table.

b Chips in posture 1 at time of sampling were introduced into column approximately 15 minutes after the last temperature observation at 2:00 p.m.

Line follows temperature program of chips located in posture 1 at 1:15 p. m., in posture 11 at 2:00 p. m., and in posture 13 at time of sampling. Since the temperatures were observed at the heater exits, the actual temperatures of the cossettes in the first postures were considerably less than the values recorded. 
TABLE 4.-Record of the temperatures observed at 15-minute intervals during approximately the time of retention of the particular charge of cossettes which at the time of sampling was situated in posture 19 of the material column in the experiment of July 23, 1925

\begin{tabular}{|c|c|c|c|c|c|c|c|c|c|}
\hline \multirow{2}{*}{ Posture } & \multirow{2}{*}{$\begin{array}{l}\text { Time of } \\
\text { retention of } \\
\text { chips }\end{array}$} & \multicolumn{7}{|c|}{ Temperatures observed at- } & \multirow{2}{*}{$\begin{array}{l}\text { Mean } \\
11: 30 \text { to } \\
\text { 12:45, } \\
\text { inclu- } \\
\text { sive }\end{array}$} \\
\hline & & $\begin{array}{l}11: 15 \\
\text { a. m. }\end{array}$ & $\begin{array}{l}11: 30 \\
\text { a. } m \text {. }\end{array}$ & $\begin{array}{l}11: 45 \\
\text { a. m. }\end{array}$ & $\begin{array}{l}\text { 12:00 } \\
\text { noon }\end{array}$ & $\begin{array}{l}12: 15 \\
\text { p. m. }\end{array}$ & $\begin{array}{l}12: 30 \\
\text { p. } \mathrm{m} .\end{array}$ & $\begin{array}{l}12: 45 \\
\text { p. m. }\end{array}$ & \\
\hline $\begin{array}{l}19 \\
18 \\
17 \\
16\end{array}$ & $\begin{array}{c}\text { Percentage of } \\
\text { whole period } \\
97.4 \\
92.1 \\
86.8 \\
81.6\end{array}$ & $\begin{array}{l}{ }^{\circ} \mathrm{C} \\
80 \\
85 \\
82 \\
80\end{array}$ & $\begin{array}{l}{ }^{\circ} \mathrm{C} \\
85 \\
85 \\
85 \\
86\end{array}$ & $\begin{array}{l}{ }^{\circ} \mathrm{C} \\
85 \\
87 \\
85 \\
80\end{array}$ & $\begin{array}{l}{ }^{\circ} \mathrm{C} \\
86 \\
80 \\
84 \\
86\end{array}$ & $\begin{array}{l}{ }^{\circ} \mathrm{C} \\
85 \\
85 \\
85 \\
83\end{array}$ & $\begin{array}{l}{ }^{\circ} \mathrm{C} \\
81 \\
81 \\
81 \\
82\end{array}$ & $\begin{array}{l}{ }^{\circ} \mathrm{C} \\
76 \\
80 \\
85 \\
86\end{array}$ & $\begin{array}{l}83.0 \\
83.0 \\
84.2 \\
83.8\end{array}$ \\
\hline $\begin{array}{l}15 \\
14 \\
13\end{array}$ & $\begin{array}{l}76.3 \\
71.1 \\
65.8\end{array}$ & $\begin{array}{l}82 \\
83 \\
84\end{array}$ & $\begin{array}{l}86 \\
87 \\
85\end{array}$ & $\begin{array}{l}82 \\
84 \\
82\end{array}$ & $\begin{array}{l}85 \\
87 \\
85\end{array}$ & $\begin{array}{l}80 \\
82 \\
83\end{array}$ & $\begin{array}{l}82 \\
82 \\
84\end{array}$ & $\begin{array}{l}80 \\
80 \\
87\end{array}$ & $\begin{array}{l}82.5 \\
83.7 \\
84.3\end{array}$ \\
\hline $12 \ldots$ & $\begin{array}{l}60.5 \\
55.3\end{array}$ & $\begin{array}{l}85 \\
83\end{array}$ & $\begin{array}{l}85 \\
85\end{array}$ & $\begin{array}{l}84 \\
81\end{array}$ & $\begin{array}{l}85 \\
84\end{array}$ & 84 & $\begin{array}{l}81 \\
80\end{array}$ & $\begin{array}{l}87 \\
87\end{array}$ & $\begin{array}{l}84.3 \\
83.5\end{array}$ \\
\hline 10 & 50.0 & 83 & 85 & 75 & 85 & 85 & 81 & 87 & 83.0 \\
\hline $\begin{array}{l}9 \\
8 \\
7 \\
7\end{array}$ & $\begin{array}{l}44.7 \\
39.5 \\
34.2\end{array}$ & $\begin{array}{l}83 \\
82 \\
81\end{array}$ & $\begin{array}{l}85 \\
85 \\
85\end{array}$ & $\begin{array}{l}84 \\
83 \\
84\end{array}$ & $\begin{array}{l}85 \\
85 \\
85\end{array}$ & $\begin{array}{l}83 \\
80 \\
80\end{array}$ & $\begin{array}{l}83 \\
84 \\
84\end{array}$ & $\begin{array}{l}85 \\
85 \\
85\end{array}$ & $\begin{array}{l}84.2 \\
83.7 \\
83.7\end{array}$ \\
\hline 6 & 28.9 & 82 & 83 & 85 & 81 & 81 & 84 & 85 & 83.2 \\
\hline $\begin{array}{l}5 \\
4 \\
4\end{array}$ & $\begin{array}{l}23.7 \\
18.4\end{array}$ & $\begin{array}{l}81 \\
75\end{array}$ & $\begin{array}{l}80 \\
77\end{array}$ & $\begin{array}{l}81 \\
72\end{array}$ & $\begin{array}{l}78 \\
78\end{array}$ & $\begin{array}{l}84 \\
83\end{array}$ & $\begin{array}{l}83 \\
80\end{array}$ & $\begin{array}{l}84 \\
84\end{array}$ & $\begin{array}{l}81.7 \\
79.0\end{array}$ \\
\hline $\begin{array}{l}3 \\
2 \\
1\end{array}$ & $\begin{array}{r}13.2 \\
7.9 \\
2.6\end{array}$ & $\begin{array}{l}80 \\
68 \\
70\end{array}$ & $\begin{array}{r}65 \\
74 \\
\ldots\end{array}$ & $\begin{array}{l}75 \\
55 \\
\end{array}$ & $\begin{array}{l}78 \\
80 \\
-\end{array}$ & $\begin{array}{l}80 \\
70 \\
70\end{array}$ & $\begin{array}{l}78 \\
70 \\
60\end{array}$ & 76 & $\begin{array}{l}75.3 \\
69.8 \\
65.0\end{array}$ \\
\hline $\begin{array}{l}\text { Means: } \\
19 \text { to } 5 \\
19 \text { to } 4 \\
19 \text { to } 1 .-\end{array}$ & $\begin{array}{l}97.4 \text { to } 23.7 \\
97.4 \text { to } 18.4 \\
97.4 \text { to } 2.6\end{array}$ & $\begin{array}{l}82.4 \\
81.9 \\
80.5\end{array}$ & $\begin{array}{l}84.8 \\
84.3 \\
82.7\end{array}$ & $\begin{array}{l}82.8 \\
82.1 \\
80.2\end{array}$ & $\begin{array}{l}84.1 \\
83.7 \\
83.2\end{array}$ & $\begin{array}{l}82.9 \\
82.9 \\
81.4\end{array}$ & $\begin{array}{l}82.2 \\
82.1 \\
80.1\end{array}$ & $\begin{array}{l}83.9 \\
83.9 \\
83.5\end{array}$ & $\begin{array}{l}83.5 \\
83.2 \\
81.1\end{array}$ \\
\hline
\end{tabular}

- Temperatures of column approximately 12 minutes before the chips in posture 19 at the time of sampling were introduced into the material column; not included in the means listed in the last column of the table.

b Chips in posture 1 at the time of sampling were introduced into the column and immediately dropped into the sample receiver approximately 10 minutes after the last observations of the temperatures were made.

The line follows approximately the temperature program of the charge which was located in posture 1 at $11: 30$, in posture 16 at $12: 45$, and in posture 19 at the time of sampling. Since the temperatures were observed at heater exits, the actual temperatures of cossettes in first postures were considerably less than those recorded.

\section{TEMPERATURE MAINTENANCE AND RATES OF HEAT LOSSES}

Although the heating of the newly charged cossettes through the operation of the flux is inadequate for a proper preparation of the material, ${ }^{10}$ the capacity of the calorisators was found ample for this purpose as well as for the maintenance of suitable temperatures in the column, even at maximum steam pressures of 1-pound gage. To estimate the proportions of steam consumed in the primary heating and in the maintenance of temperatures under different conditions of room ventilation, three tests were made with water in place of cossettes and flood liquid. To appraise the rates of heat losses on the basis of exposed area as well as on the basis of the column length, the area of the exposed surfaces of the cells and manifolds without insulation was estimated by a detailed consideration of the various elements of the structure. The result is approximately $3.5 \mathrm{ft}^{2}$ per cell. In each of the three tests the column comprised 18 cells. Charges of 1 $\mathrm{kg}$ of cold water were introduced at 5-minute intervals, primed with the efflux from the column, and drawn at a rate similar to the drawing rates in the experimental extractions. From the total heat consumed 
there was deducted the sum of the quantities recovered (1) in the water discharged as "residues" at the head of the column; (2) as "draft" at the foot; and (3) in the condensate issuing from all calorisators and heaters. The remainder is assumed to have been heat lost to the surroundings by "radiation", but including that transferred by conduction and convection. The results are presented in table 5 .

TABLE 5.-Estimated rates of heat loss from the experimental battery

\begin{tabular}{|c|c|c|c|c|c|c|c|c|c|c|c|}
\hline \multirow[b]{2}{*}{ Test } & \multirow{2}{*}{$\begin{array}{l}\text { Dura- } \\
\text { tion } \\
\text { of } \\
\text { test }\end{array}$} & \multirow{2}{*}{$\begin{array}{c}\text { Aver- } \\
\text { age } \\
\text { tem- } \\
\text { pera- } \\
\text { ture } \\
\text { battery }\end{array}$} & \multirow{2}{*}{$\begin{array}{l}\text { Tem- } \\
\text { pera- } \\
\text { ture } \\
\text { of } \\
\text { room }\end{array}$} & \multirow{2}{*}{$\begin{array}{l}\text { Tem- } \\
\text { pera- } \\
\text { ture } \\
\text { differ- } \\
\text { ence }\end{array}$} & \multirow{2}{*}{$\begin{array}{l}\text { Total } \\
\text { heat in } \\
\text { steam } \\
\text { con- } \\
\text { sumed }\end{array}$} & \multirow{2}{*}{$\begin{array}{l}\text { Heat } \\
\text { con- } \\
\text { sumed } \\
\text { in } \\
\text { heat- } \\
\text { ing } \\
\text { water }\end{array}$} & \multirow{2}{*}{$\begin{array}{l}\text { Total } \\
\text { heat } \\
\text { lost to } \\
\text { sur- } \\
\text { round- } \\
\text { ings } \\
\text { through } \\
\text { "radia- } \\
\text { tion" }\end{array}$} & \multicolumn{2}{|c|}{$\begin{array}{l}\text { Rate of loss in } 18 \\
\text { cells }\end{array}$} & \multirow{2}{*}{$\begin{array}{l}\text { Rate of } \\
\text { loss per } \\
\text { cell }\end{array}$} & \multirow{2}{*}{$\begin{array}{c}\text { Over-all } \\
\text { coefficient } \\
\text { of heat } \\
\text { transfer } \\
\text { per } \\
\text { square } \\
\text { foot of } \\
\text { surface }\end{array}$} \\
\hline & & & & & & & & $\begin{array}{c}\text { Tem- } \\
\text { pera- } \\
\text { ture } \\
\text { differ- } \\
\text { ence }\end{array}$ & $\begin{array}{l}\text { Tem- } \\
\text { perature } \\
\text { differ- } \\
\text { ence }\end{array}$ & & \\
\hline & $\begin{array}{r}\min . \\
24 \\
19 \\
24\end{array}$ & $\begin{array}{l}{ }^{\circ} \mathrm{C} \\
72.7 \\
73.0 \\
54.0\end{array}$ & $\begin{array}{l}{ }^{\circ} \mathrm{C} \\
26.0 \\
26.0 \\
28.0\end{array}$ & $\begin{array}{l}{ }^{\circ} \mathrm{C} \\
46.7 \\
47 . \mathrm{C} \\
26.0\end{array}$ & $\begin{array}{l}\mathrm{ke} \\
6,351 \\
5,070 \\
5,238\end{array}$ & $\begin{array}{c}\mathbf{k c} \\
1,721 \\
1,711 \\
1,438\end{array}$ & $\begin{array}{c}\mathrm{ke} \\
4,630 \\
3,359 \\
3,755\end{array}$ & $\begin{array}{c}\mathrm{kc} / \mathrm{hr} /{ }^{\circ} \mathrm{C} \\
247.6 \\
225.7 \\
361.0\end{array}$ & $\begin{array}{l}\text { Btu/ } \\
\mathrm{hr} /{ }^{\circ} \mathrm{F} \\
546.0 \\
497.7 \\
796.2\end{array}$ & 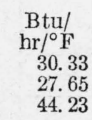 & $\begin{array}{r}\mathrm{Btu} / \\
\mathrm{hr} /{ }^{\circ} \mathrm{F} \\
8.67 \\
7.80 \\
12.64\end{array}$ \\
\hline Mean . & & & & & & & & 278 & 613 & 34 & 9.7 \\
\hline
\end{tabular}

The fact that the ventilation of the room was considerably better during the third test than during the others may account for the greater rate of heat loss in this case. Of the total heat consumed, the proportion lost was about the same in this test as in test 1, although the mean temperature of the battery was considerably less in test 3 .

\section{TEMPERATURE SCHEDULES}

In most of the experiments the aim was to bring the cossettes to a temperature of about $80^{\circ} \mathrm{C}$ as rapidly as possible and to maintain this temperature during the remainder of the processing. In the experiment of July 23, the aim was to establish a temperature gradient from the head of the column to the middle. In two other experiments the aim was to maintain a steadily rising temperature during the retention of the cossettes. Table 6 presents the mean of all the observations of the temperature of the flood liquid taken at the heater exit of each posture in each July experiment; and tables 3 and 4 indicate the general run of variations among individual observations. Item 12a of table 6 presents the temperature schedule planned for the experiment of July 24 ; item $12 \mathrm{~b}$, the means of all the temperatures observed for each posture during the run. Since every value in each table represents the respective temperature after the flood liquid had received the increment supplied by the calorisator following the posture, it is more or less greater than the temperature which actually existed in the bottom of the posture. For the postures near the foot of any column the increments may have amounted to as much as $15^{\circ}$. It is for this reason that the installation of thermometers near the centers of the cells has been recommended in the construction of similar equipment. ${ }^{11}$

${ }^{11}$ J. Research NBS 15, 455 and 1272 (1935) RP840. 
TABLE 6.-Temperature schedules

[Experiments for July 1925]

Each value listed is the observed (or planned) mean temperature for the posture indicated during the whole run of the experiment

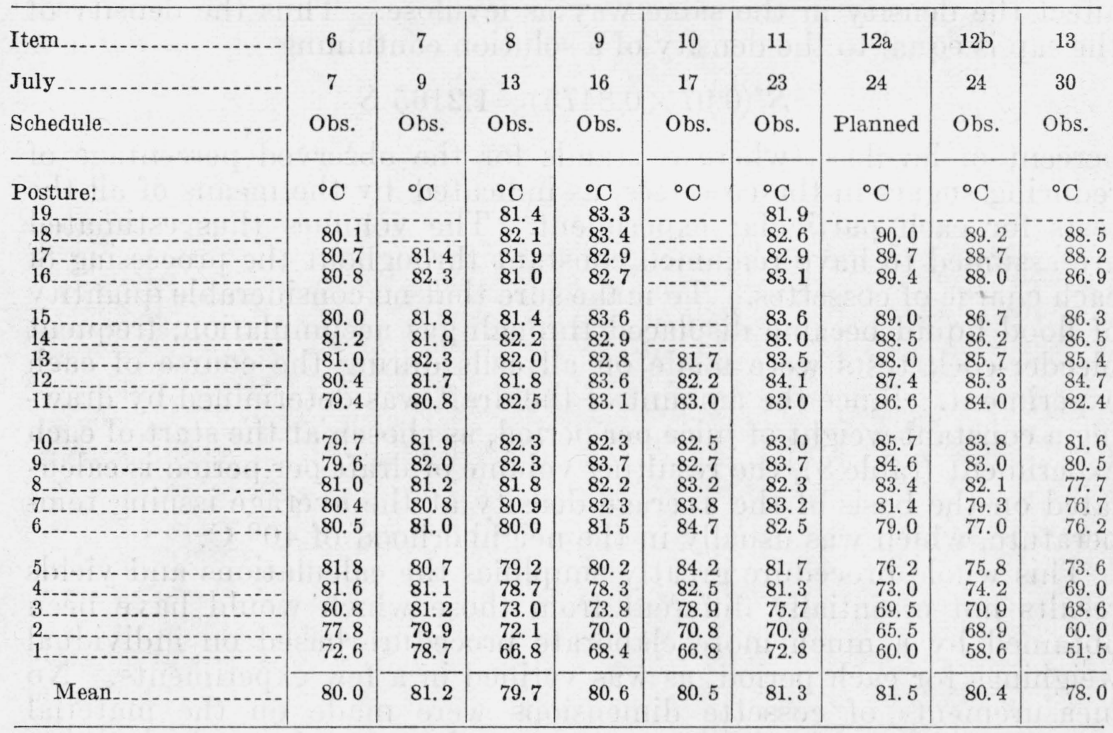

Mean of all except columns 10 and $12 \mathrm{a}$

80.3

\section{WORKING VOLUMES}

The mean volumetric capacity of a cell is assumed to be approximately $1.9 \mathrm{dm}^{3}$. The mean value found by weighing more than 100 cellfuls of water at about $20^{\circ} \mathrm{C}$, from six fillings of the battery, is 1.884 $\mathrm{dm}^{3}$. The mean value calculated from the observed dimensions of the cells is the same. The index of variability of the weighings is equivalent to about $0.027 \mathrm{dm}^{3}$, and the maximum deviation from the mean is about $0.1 \mathrm{dm}^{3}$. Since the greater part of the indicated variation is due to differences in the capacities of the cells, rather than to accidental deviations in measurement, the cells are by no means uniform in size. Allowing for the expansion of cast brass between 20 and $80^{\circ} \mathrm{C}$ indicates a mean volumetric capacity of approximately the $1.9 \mathrm{dm}^{3}$ assumed as a round value. This probably allows for only a part of the flood liquid in the transfer ducts.

The working volume of the flood liquid per cell is assumed to have been equal to the difference between the mean volumetric capacity of a cell and the displacement volume of the mean charge of cossettes for each experiment, all at $80^{\circ} \mathrm{C}$. The displacement volume of $1 \mathrm{~kg}$ of cossettes is assumed to have been the sum of the volumes occupied by $30 \mathrm{~g}$ of marc and $970 \mathrm{~g}$ of virgin sap. In all cases the $30 \mathrm{~g}$ of marc is supposed to have occupied a volume of $0.01736 \mathrm{dm}^{3}$ at the operating temperature of the battery. This is approximately the mean of several quantitative estimations obtained by extracting cossettes prepared from artichoke tubers from various sources, but it does not represent directly any of the material used in the extractions here reported. In each case the density of the virgin sap is calculated on 
the assumption that it is due to the presence in the sap of all the reducing sugars observed in the cossettes, accompanied by such a quantity of other solid substances as to yield an apparent purity of 84.75 percent reducing sugars, and that all of these dissolved substances affect the density in the same way as levulose. Thus the density of the sap is equal to the density of a solution containing

$$
S /(0.97 \times 0.8475)=1.2165 S
$$

percent of levulose, where $S$ stands for the observed percentage of reducing sugars in the cossettes, as indicated by the means of all the tests for each particular experiment. The volumes thus estimated are assumed to have remained constant throughout the processing of each charge of cossettes. To make sure that no considerable quantity of flood liquid became displaced through gas accumulation, frequent bleeder-cock tests were made on all cells during the course of each experiment. Since the amount of the draft was determined by drawing a constant weight of juice per period, as chosen at the start of each experiment (table 8), the resulting volume of draft per period is calculated on the basis of the average density at the average issuing temperature, which was usually in the neighborhood of $40^{\circ} \mathrm{C}$.

This whole procedure greatly simplifies the calculations and yields results not essentially different from those which would have been obtained by a much more elaborate procedure based on individual weighings for each period, as was verified in a few experiments. No measurements of cossette dimensions were made on the material actually employed in the extraction experiments. Instead, the gross area of the diffusion layers in each case is assumed to have been 2.6 $\mathrm{m}^{2} / \mathrm{dm}^{3}$ of the calculated displacement volume of the cossettes, as estimated for a different lot of material and previously reported. ${ }^{2}$ No corrections are essayed for the effects of either the adherent films or the area rendered ineffective through contacts of surfaces.

\section{TYPICAL EXTRACTION DATA}

The principal recorded data on the charging, operation, and over-all performance of the extraction columns established in 13 early experiments conducted in the straight arrangement of the cells are presented in tables 7 to 13 , inclusive. These experiments include the three in which the column was sampled at the end of the run, with the results already presented in table 2. They include also the five experiments in which data on the performance during sweetening off are compared with those during normal operation (table 1).

Of the three sampled columns, two may be classed as long, the other as of medium length. In this sense length applies to the term of processing, rather than to the physical dimensions of the equipment; and it refers to the extraction of polysaccharides from artichoke cossettes of the dimensions specified, not to the diffusion of other material. In beet sugar practice a 13-cell column might be considered long rather than of medium length. The general set-up of each column is presented in table 7. A brief of the operating data (exclusive of temperatures, table 6 ) is presented in table 8 .

12 J. Research NBS 17, 615 (1936) RP931. 
TABLE 7.-Data on sot-up of columns and durations of runs in 13 experiments $A=$ total or average for April; $B=$ total or average for July; $C=$ total or average for July exclusive of July 17 ; $D=$ total or average for all experiments in the list

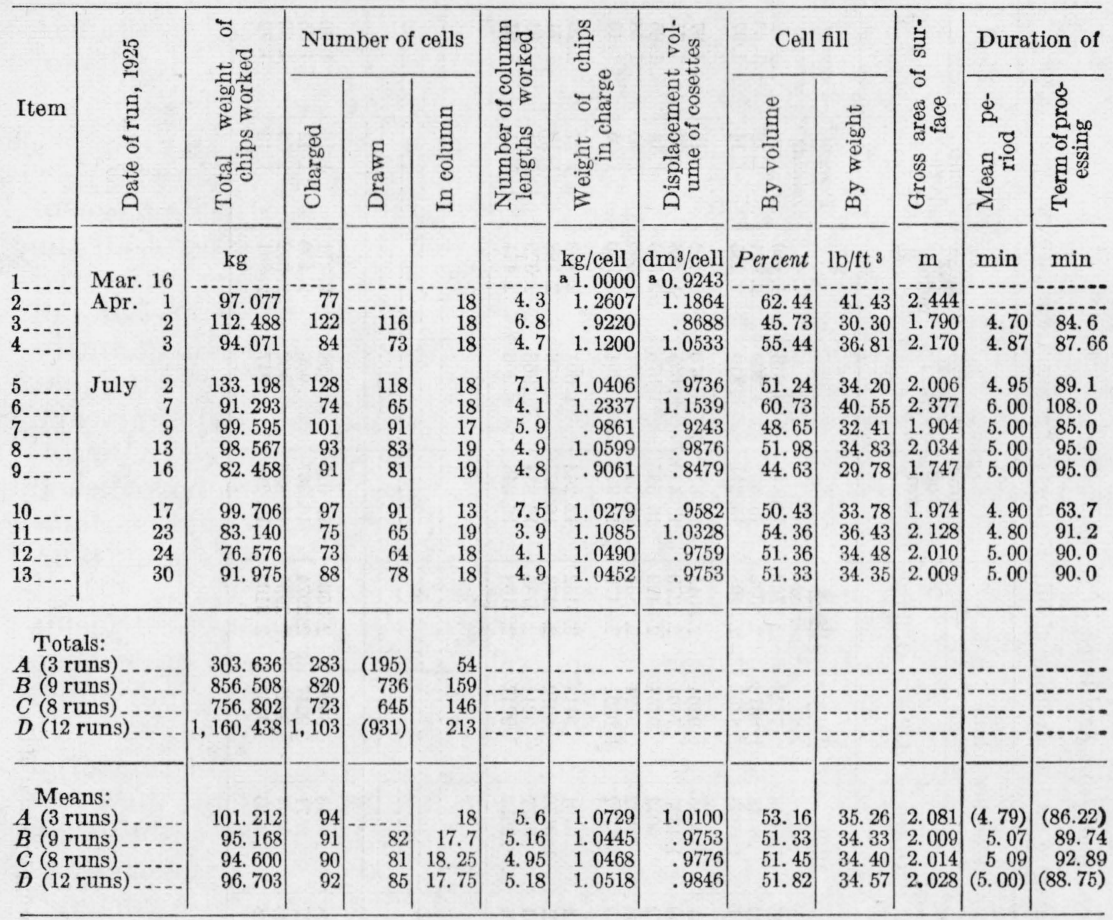

- For this one run the displacement volume is expressed as $\mathrm{dm}^{3} / \mathrm{kg}$, since the mean charge is not recorded. 
TABLE 8.-Brief of data on operation exclusive of temperatures

$A=$ total or average for April; $B=$ total or average for July; $C=$ total or average for July exclusive of July $17 ; D=$ total or average for all experiments in the list

\begin{tabular}{|c|c|c|c|c|c|c|c|c|c|c|c|c|c|}
\hline \multirow[b]{2}{*}{ Item } & \multirow{2}{*}{$\begin{array}{c}\text { Date of } \\
\text { run, } 1925\end{array}$} & \multicolumn{2}{|c|}{ Draft } & \multicolumn{4}{|c|}{ Working volume } & \multirow{2}{*}{$\begin{array}{l}\text { Volume } \\
\text { of flood } \\
\text { column }^{2}\end{array}$} & \multirow{2}{*}{$\begin{array}{l}\text { Flood } \\
\text { ratio }^{3}\end{array}$} & \multirow{2}{*}{$\underset{\text { ratio }}{\text { Flux }}$} & \multirow{2}{*}{$\begin{array}{c}\text { Chip } \\
\text { advance- } \\
\text { ment }^{5}\end{array}$} & \multicolumn{2}{|c|}{ Flood recession } \\
\hline & & $\begin{array}{c}\text { By } \\
\text { weight }\end{array}$ & $\begin{array}{l}\text { On } \\
\text { chips }\end{array}$ & Of draft & Of sap & Of flood & Of flux ${ }^{1}$ & & & & & $\begin{array}{c}\text { Per } \\
\text { minute }{ }^{6}\end{array}$ & Relative $^{7}$ \\
\hline & $\begin{array}{ll}\text { Apr. } & 1 \\
2 \\
3\end{array}$ & $\begin{array}{l}\frac{\mathrm{kg}}{\mathrm{period}} \\
1.493 \\
1.493 \\
1.493\end{array}$ & \begin{tabular}{|c|} 
Percent \\
118 \\
162 \\
133
\end{tabular} & $\begin{array}{l}\frac{\mathrm{dm}^{3}}{\text { period }} \\
1.4626 \\
1.4620 \\
1.4641\end{array}$ & $\begin{array}{l}\frac{\mathrm{dm}^{3}}{\text { cell }} \\
1.1646 \\
.8528 \\
1.0338\end{array}$ & $\begin{array}{l}\frac{\mathrm{dm}^{3}}{\text { cell }} \\
0.7136 \\
1.0312 \\
.8467\end{array}$ & $\begin{array}{l}\frac{\mathrm{dm}^{3}}{\text { period }} \\
\text { 2. } 1762 \\
2.4932 \\
2.3108\end{array}$ & $\begin{array}{l}\mathrm{dm} 3^{3} \\
\text { 12. } 844 \\
\text { 18. } 562 \\
\text { 15. } 241\end{array}$ & $\begin{array}{r}0.613 \\
1.209 \\
.819\end{array}$ & $\begin{array}{l}1.869 \\
2.924 \\
2.235\end{array}$ & $\begin{array}{c}\frac{\text { Percent }}{\text { minute }} \\
1.18 \\
1.14\end{array}$ & $\begin{array}{r}\frac{\text { Percent }}{\text { minute }} \\
1.68 \\
1.97\end{array}$ & $\begin{array}{r}\text { Percent } \\
\text { percent } \\
2.05 \\
1.42 \\
1.73\end{array}$ \\
\hline $\begin{array}{l}5-1 \\
6 \\
7 \\
8 \\
9\end{array}$ & $\begin{array}{|rr|}\text { July } & 2 \\
& 7 \\
9 \\
\\
13 \\
16\end{array}$ & $\begin{array}{l}1.421 \\
1.420 \\
1.411 \\
1.421 \\
1.440\end{array}$ & $\begin{array}{l}137 \\
115 \\
143 \\
134 \\
159\end{array}$ & $\begin{array}{l}\text { 1. } 3781 \\
\text { 1. } 3809 \\
\text { 1. } 3672 \\
\text { 1. } 3706 \\
1.3949\end{array}$ & $\begin{array}{r}.9555 \\
1.1325 \\
.9072 \\
.9692 \\
.8322\end{array}$ & $\begin{array}{r}.9264 \\
.7461 \\
.9757 \\
.9124 \\
1.0521\end{array}$ & $\begin{array}{l}2.3045 \\
2.1270 \\
2.3429 \\
2.2830 \\
2.4470\end{array}$ & $\begin{array}{l}16.676 \\
13.430 \\
16.587 \\
17.336 \\
19.990\end{array}$ & $\begin{array}{r}.970 \\
.659 \\
1.076 \\
.941 \\
1.264\end{array}$ & $\begin{array}{l}2.412 \\
1.878 \\
2.583 \\
2.356 \\
2.940\end{array}$ & $\begin{array}{l}1.12 \\
.93 \\
1.18 \\
1.05 \\
1.05\end{array}$ & $\begin{array}{l}1.67 \\
1.71 \\
1.65 \\
1.58 \\
1.40\end{array}$ & $\begin{array}{l}1.49 \\
1.85 \\
1.40 \\
1.50 \\
1.33\end{array}$ \\
\hline 110 & $\begin{array}{l}17 \\
23 \\
24 \\
30 \\
\end{array}$ & $\begin{array}{l}1.417 \\
1.400 \\
1.402 \\
1.430 \\
\end{array}$ & $\begin{array}{l}138 \\
127 \\
134 \\
137 \\
\end{array}$ & $\begin{array}{l}\text { 1. } 3714 \\
\text { 1. } 3501 \\
\text { 1. } 3544 \\
\text { 1. } 3861 \\
\end{array}$ & $\begin{array}{r}.9404 \\
1.0136 \\
.9577 \\
.9572 \\
\end{array}$ & $\begin{array}{l}.9418 \\
.8672 \\
.9241 \\
.9247 \\
\end{array}$ & $\begin{array}{l}2.3132 \\
2.2173 \\
2.2785 \\
2.3108 \\
\end{array}$ & $\begin{array}{l}12.243 \\
16.477 \\
16.634 \\
16.645 \\
\end{array}$ & $\begin{array}{r}1.001 \\
.856 \\
.965 \\
.966 \\
\end{array}$ & $\begin{array}{l}2.460 \\
2.188 \\
2.379 \\
2.414 \\
\end{array}$ & $\begin{array}{l}1.57 \\
1.10 \\
1.11 \\
1.11 \\
\end{array}$ & \begin{tabular}{l|}
2.29 \\
1.71 \\
1.63 \\
1.67 \\
\end{tabular} & $\begin{array}{l}1.46 \\
1.56 \\
1.47 \\
1.50 \\
\end{array}$ \\
\hline $\begin{array}{l}\text { Totals: } \\
A \text { (3 runs) } \\
B \text { (9 runs) } \\
C \text { (8 runs) } \\
D \text { (12 runs) }\end{array}$ & & $\begin{array}{r}4.479 \\
12.762 \\
11.345 \\
17.241 \\
\end{array}$ & - & & & $\cdots$ & - & & & & & & 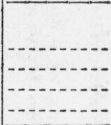 \\
\hline $\begin{array}{l}\text { Means: } \\
A \text { (3 runs) } \\
B \text { (9 runs) }-\ldots \\
C \text { (8 runs) } \\
D \text { (12 runs) }\end{array}$ & $-\cdots$ & $\begin{array}{l}1.493 \\
1.418 \\
1.418 \\
1.437\end{array}$ & $\begin{array}{l}139 \\
136 \\
135 \\
137\end{array}$ & $\begin{array}{l}1.4608 \\
1.3727 \\
1.3726 \\
1.3948\end{array}$ & $\begin{array}{l}.9913 \\
.9571 \\
.9594 \\
.9663\end{array}$ & $\begin{array}{l}.8900 \\
.9247 \\
.9225 \\
.9154\end{array}$ & $\begin{array}{l}2.3508 \\
2.2974 \\
2.2951 \\
2.3102\end{array}$ & $\begin{array}{l}\text { 16. } 020 \\
\text { 16. } 367 \\
16.836 \\
16.248\end{array}$ & $\begin{array}{l}.898 \\
.966 \\
.962 \\
.947\end{array}$ & $\begin{array}{l}2.371 \\
2.400 \\
2.392 \\
2.391\end{array}$ & $\begin{array}{l}1.16 \\
1.11 \\
1.08 \\
1.13\end{array}$ & $\begin{array}{l}1.90 \\
1.65 \\
1.60 \\
1.72\end{array}$ & $\begin{array}{l}1.64 \\
1.48 \\
1.49 \\
1.52\end{array}$ \\
\hline
\end{tabular}

1 Volume of flux $=$ volume of draft + volume of flood.

2 Volume of flood column $=n$ times volume of flood/cell.

${ }^{3}$ Flood ratio $=\frac{\text { volume of flood }}{\text { volume of sap }}=\frac{v^{\prime \prime}}{v^{\prime}}$.

4 Flux ratio $=$ volume of flux $=f^{\prime}$

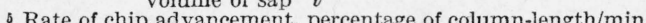

Rate of chip advancement, percentage of column-length/min.

7 Rate expressed as column-length per period or percentage of column-length during 1 percent of the term. 


\section{GROSS RATES OF EXTRACTION}

Data pertaining to the gross rates of extraction attained in the 13 experiments are presented in table 9. Comparing the over-all performance of the 13-cell column (item 10) with the mean for all of the longer columns set up in July (average $C$ ), it will be seen that the column of medium length produced a lower gross extraction (92.5 percent vs. 97.4 percent), of which a greater proportion (0.92 percent vs. 0.50 percent) was discarded in the pulp water. If the ultimate objective is continuous extraction in a true sense, this is an important consideration; for in the intermittent process the polysaccharides discarded in the pulp water were extracted, although not recovered. The mean rate of the gross extraction for the whole column was decidedly greater in the shorter column $\left(1.01 \mathrm{~g} / \mathrm{m}^{2} / \mathrm{min}\right.$ vs. $\left.0.762 \mathrm{~g} / \mathrm{m}^{2} / \mathrm{min}\right)$, although the relative flood recession per period was slightly less (1.46 vs. 1.49 , table 8$)$. Any error in the assumption that the effective areas of the diffusion layers were strictly proportional to the respective displacement volumes of the cossettes probably would influence the calculated rates not very differently in the two cases. The fact that relatively little change appeared in the analyses of the cossettes during July ${ }^{13}$ leads to the belief that with the constant knife setting employed any variations in the dimensions of the cossettes influenced the rates of diffusion negligibly compared with the effects due to variations in the density of filling. Very probably when the density of filling passes a certain critical value which has not been determined definitely, the available area cannot remain directly proportional to the displacement volume but must fall off at an accelerating rate. The data per se present no obvious evidence that this value was exceeded in more than one experiment among the 8 included in average $C$. Not excluding this one experiment of July 7 , the mean density of filling was but $0.6 \mathrm{lb} / \mathrm{ft}^{3}$ greater in the longer columns. The mean temperatures for the respective whole runs were practically identical $\left(80.5^{\circ}\right.$ vs. $\left.80.3^{\circ}\right)$.

${ }_{13}$ The cossettes were all cut from the same general lot of tubers kept under cold storage. The tubers for each experiment were removed on the day they were to be sliced. 
TABLE 9.-Gross extraction

\begin{tabular}{|c|c|c|c|c|c|c|c|c|c|c|c|c|}
\hline \multirow{2}{*}{ Item } & \multirow{2}{*}{$\begin{array}{l}\text { Date of } \\
\text { run, } 1925\end{array}$} & \multicolumn{2}{|c|}{ Analysis of cossettes } & \multicolumn{2}{|c|}{$\begin{array}{l}\text { Reducing sugars } \\
\text { at } 80^{\circ} \mathrm{C}\end{array}$} & \multicolumn{3}{|c|}{$\begin{array}{l}\text { Weight of reducing sugars } \\
\text { per cell in- }\end{array}$} & \multicolumn{2}{|c|}{$\begin{array}{l}\text { Extracted in } \\
\text { whole column }\end{array}$} & \multirow{2}{*}{\multicolumn{2}{|c|}{$\begin{array}{l}\text { Mean rate of ex- } \\
\text { traction for whole } \\
\text { column }\end{array}$}} \\
\hline & & Levulose & $\begin{array}{c}\text { Reducing } \\
\text { sugars }\end{array}$ & $\begin{array}{l}\text { In pulp } \\
\text { sap } 1\end{array}$ & $\begin{array}{l}\text { In pulp } \\
\text { water }{ }^{1}\end{array}$ & $\begin{array}{c}\text { Fresh } \\
\text { sap }\end{array}$ & $\begin{array}{l}\text { Pulp } \\
\text { sap }\end{array}$ & $\begin{array}{l}\text { Pulp } \\
\text { water }\end{array}$ & Period & $\begin{array}{c}\text { On } \\
\text { charge }\end{array}$ & & \\
\hline $1 .$. & $\begin{array}{r}\text { Mar. } 16 \\
16 \\
16 \\
16 \\
16\end{array}$ & $\begin{array}{c}\text { Percent } \\
8.7 \\
8.65 \\
8.25 \\
8.65\end{array}$ & $\begin{array}{c}\text { Percent } \\
12.2 \\
12.3 \\
11.9 \\
12.4\end{array}$ & $\begin{array}{r}\mathrm{g} / 100 \mathrm{ml} \\
1.100 \\
1.227 \\
2.317 \\
4.275 \\
4.401\end{array}$ & $\begin{array}{r}\mathrm{g} / 100 \mathrm{ml} \\
0.256 \\
.276 \\
\end{array}$ & $\begin{array}{c}\mathrm{g} \\
\\
\\
\end{array}$ & $\begin{array}{c}\mathrm{g} \\
311.00 \\
312.27 \\
323.17 \\
342.75 \\
344.01\end{array}$ & \begin{tabular}{c}
$\mathrm{g}$ \\
32.56 \\
32.76 \\
\hdashline$-1 .-$ \\
-0
\end{tabular} & 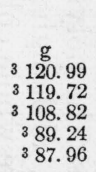 & $\begin{array}{r}\text { Percent } \\
91.67 \\
90.70 \\
82.45 \\
67.61 \\
66.66\end{array}$ & $\begin{array}{r}\frac{\mathrm{g} / \mathrm{m}^{2}}{\text { period }} \\
3.47 \\
3.43 \\
3.12 \\
2.56 \\
2.52\end{array}$ & $\begin{array}{c}\frac{\mathrm{g} / \mathrm{m}^{2}}{\text { minute }} \\
\\
\end{array}$ \\
\hline Average. & $\ldots$ & 8. 563 & 12.20 & 2.665 & .266 & 3131.99 & 326.63 & 32.66 & 3105.36 & 79.82 & 3.02 & $(0.604)$ \\
\hline $2 \ldots$ & $\begin{array}{ll}\text { Apr. } & 1 \\
& 1 \\
& 1 \\
& 1\end{array}$ & $\begin{array}{r}9.34 \\
\end{array}$ & $\begin{array}{l}12.72 \\
12.54 \\
11.72 \\
\end{array}$ & $\begin{array}{r}3.320 \\
2.201 \\
.750 \\
.701\end{array}$ & $\begin{array}{l}.356 \\
.178 \\
.083\end{array}$ & $\begin{array}{c} \\
\end{array}$ & $\begin{array}{r}38.66 \\
25.63 \\
8.73 \\
8.16\end{array}$ & $\begin{array}{l}2.54 \\
1.27 \\
.59\end{array}$ & $\begin{array}{l}116.75 \\
128.78 \\
146.68 \\
147.25\end{array}$ & $\begin{array}{l}75.12 \\
82.86 \\
94.38 \\
94.75\end{array}$ & $\begin{array}{l}2.65 \\
2.93 \\
3.33 \\
3.35\end{array}$ & $\begin{array}{c} \\
\end{array}$ \\
\hline Average. & -- & 9.34 & 12.327 & 1.743 & .205 & 155.41 & 20.30 & 1.46 & 135.11 & 86.94 & 3.07 & $(0.614)$ \\
\hline $3 \ldots$ & $\begin{array}{ll}\text { Apr. } & 2 \\
& 2 \\
2 \\
2 \\
2 \\
2\end{array}$ & $\begin{array}{r}9.81 \\
9.26 \\
\end{array}$ & $\begin{array}{r}11.74 \\
12.35 \\
\end{array}$ & $\begin{array}{l}.944 \\
.964 \\
.252 \\
.633 \\
.789\end{array}$ & $\begin{array}{l}.350 \\
.224 \\
.136 \\
.117 \\
.127\end{array}$ & \begin{tabular}{|c|} 
\\
$\ldots \ldots$ \\
\end{tabular} & $\begin{array}{l}8.05 \\
8.22 \\
2.15 \\
5.40 \\
6.73\end{array}$ & $\begin{array}{l}3.60 \\
2.31 \\
1.40 \\
1.21 \\
1.31\end{array}$ & $\begin{array}{l}163.07 \\
102.90 \\
108.97 \\
105.72 \\
104.39\end{array}$ & $\begin{array}{l}92.76 \\
92.60 \\
98.07 \\
95.14 \\
93.94\end{array}$ & $\begin{array}{l}3.12 \\
3.19 \\
3.38 \\
3.28 \\
3.24\end{array}$ & 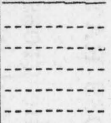 \\
\hline A verage... & & 9. 535 & 12.065 & .796 & .191 & 111.12 & 6. 79 & 1.97 & 104.33 & 93.89 & 3.24 & 0.689 \\
\hline 4... & \begin{tabular}{|cc} 
Apr. & 3 \\
& 3 \\
& 3 \\
& 3
\end{tabular} & $\begin{array}{c}9.06 \\
\end{array}$ & $\begin{array}{c}12.35 \\
\end{array}$ & $\begin{array}{l}.341 \\
.624 \\
.633 \\
.994\end{array}$ & $\begin{array}{l}.068 \\
.136 \\
.117 \\
.234\end{array}$ & $\begin{array}{l} \\
\end{array}$ & $\begin{array}{r}3.53 \\
6.45 \\
6.54 \\
10.28\end{array}$ & $\begin{array}{r}.58 \\
1.15 \\
.99 \\
1.98\end{array}$ & $\begin{array}{l}134.79 \\
131.87 \\
131.78 \\
128.04\end{array}$ & $\begin{array}{l}97.45 \\
95.34 \\
95.27 \\
92.57\end{array}$ & $\begin{array}{l}3.45 \\
3.38 \\
3.37 \\
3.28\end{array}$ & $\begin{array}{c} \\
\\
\end{array}$ \\
\hline Average.. & & 9.06 & 12.35 & .648 & .139 & 138. 32 & 6.70 & 1.18 & 131.62 & 95.16 & 3. 37 & .692 \\
\hline $5 \ldots$ & \begin{tabular}{|cc} 
July & 2 \\
& 2 \\
& 2 \\
& 2 \\
& 2
\end{tabular} & $\begin{array}{r}10.65 \\
10.40 \\
\end{array}$ & $\begin{array}{l}13.82 \\
13.24 \\
\\
\end{array}$ & $\begin{array}{l}1.402 \\
1.908 \\
1.032 \\
.662 \\
.662\end{array}$ & $\begin{array}{l}.104 \\
.093 \\
.135 \\
.153 \\
.181\end{array}$ & \begin{tabular}{|c|} 
\\
\\
\end{tabular} & $\begin{array}{r}13.40 \\
18.23 \\
9.86 \\
6.33 \\
6.33\end{array}$ & $\begin{array}{r}.96 \\
.88 \\
1.25 \\
1.42 \\
1.68\end{array}$ & $\begin{array}{l}127.39 \\
122.56 \\
130.93 \\
134.46 \\
134.46\end{array}$ & $\begin{array}{l}90.48 \\
87.07 \\
93.00 \\
95.50 \\
95.50\end{array}$ & $\begin{array}{l}3.53 \\
3.39 \\
3.63 \\
3.72 \\
3.72\end{array}$ & 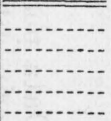 \\
\hline Average. & & 10.525 & 13. 53 & 1. 133 & .133 & 140.79 & 10.83 & 1.23 & 129.96 & 92.31 & 3. 60 & .727 \\
\hline
\end{tabular}




\begin{tabular}{|c|c|c|c|c|c|c|c|c|c|c|c|c|}
\hline $6 \ldots$ & July 7 & 10.32 & 13. 58 & $\begin{array}{l}.166 \\
.182 \\
\end{array}$ & $.027 \mid$ & - & $\begin{array}{l}1.88 \\
2.08 \\
\end{array}$ & $\begin{array}{l}.20 \\
.16 \\
\end{array}$ & $\begin{array}{l}165.66 \\
165.48 \\
\end{array}$ & $\begin{array}{l}98.88 \\
98.77 \\
\end{array}$ & $\begin{array}{l}3.87 \\
3.87 \\
\end{array}$ & - \\
\hline A verag & & 10.32 & 13.58 & .174 & .024 & 167.54 & 1.97 & .18 & 165.57 & 98.82 & 3.87 & .645 \\
\hline & July & $\begin{array}{r}9.46 \\
10.71 \\
\end{array}$ & $\begin{array}{l}12.67 \\
13.64 \\
\end{array}$ & $\begin{array}{l}.161 \\
.363 \\
.214 \\
.477 \\
\end{array}$ & $\begin{array}{l}.040 \\
.085 \\
.050 \\
.072 \\
\end{array}$ & \begin{tabular}{|l|} 
\\
\\
\end{tabular} & $\begin{array}{l}1.46 \\
\text { 3. } 29 \\
1.94 \\
4.33 \\
\end{array}$ & $\begin{array}{l}.39 \\
.83 \\
.49 \\
.70 \\
\end{array}$ & \begin{tabular}{l|}
128.26 \\
126.43 \\
127.78 \\
125.39
\end{tabular} & $\begin{array}{l}98.87 \\
97.46 \\
98.50 \\
96.66\end{array}$ & $\begin{array}{l}3.96 \\
3.91 \\
3.95 \\
3.87\end{array}$ & \begin{tabular}{|c|c|}
-1 \\
-2
\end{tabular} \\
\hline Average... & & 10.085 & 13.155 & .308 & .054 & 129.72 & 2.79 & .53 & 126.93 & 97.86 & 3.92 & .784 \\
\hline Sweetening off; not in average. & & (n)......... & - & .438 & .232 & 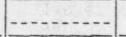 & 3.97 & 2.26 & 125.75 & 96.94 & 3.89 & $\ldots$ \\
\hline 8... & $\begin{array}{rr}\text { July } & 13 \\
13 \\
13 \\
13\end{array}$ & $\begin{array}{l}11.13 \\
10.47\end{array}$ & \begin{tabular}{l}
14.51 \\
14.21 \\
\hdashline
\end{tabular} & $\begin{array}{l}.334 \\
.354 \\
.283 \\
.248 \\
\end{array}$ & $\begin{array}{l}.062 \\
.085 \\
.087\end{array}$ & $\begin{array}{l}\ldots \\
\end{array}$ & $\begin{array}{l}3.74 \\
3.43 \\
2.74 \\
2.40 \\
\end{array}$ & $\begin{array}{l}.57 \\
.78 \\
.79 \\
. .-\end{array}$ & $\begin{array}{l}148.46 \\
148.77 \\
149.46 \\
149.80 \\
\end{array}$ & $\begin{array}{l}97.54 \\
97.75 \\
98.20 \\
98.42 \\
\end{array}$ & $\begin{array}{l}384 \\
3.85 \\
3.87 \\
3.88 \\
\end{array}$ & - \\
\hline A verage. & & 10.80 & 14. 36 & .305 & .078 & 152.20 & 2.96 & .71 & 149.24 & 98.06 & 3.86 & .772 \\
\hline Sẁeetening off; not in average.. & & -.......... & 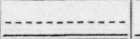 & .348 & .182 & $\ldots \ldots \ldots$ & 3.37 & 1.66 & 148.83 & 97.79 & 3.85 & $2 \ldots \ldots$ \\
\hline 9 & $\begin{array}{ll}\text { July } & 16 \\
& 16 \\
& 16\end{array}$ & $\begin{array}{c}10.06 \\
\end{array}$ & $\begin{array}{l}13.49 \\
\end{array}$ & $\begin{array}{l}.217 \\
.270 \\
.311 \\
\end{array}$ & .064 & 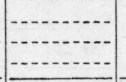 & $\begin{array}{l}1.81 \\
2.25 \\
2.59 \\
\end{array}$ & $\begin{array}{r}.67 \\
\end{array}$ & $\begin{array}{l}120.42 \\
119.98 \\
119.64 \\
\end{array}$ & $\begin{array}{l}98.52 \\
98.16 \\
97.88 \\
\end{array}$ & $\begin{array}{l}3.63 \\
3.61 \\
3.60 \\
\end{array}$ & - \\
\hline Average. & & 10.06 & 13. 49 & .266 & .064 & 122.23 & 2.21 & .67 & 120.02 & 98.19 & 3.62 & .723 \\
\hline Sweetening off, not in average.... & & -....... & . & $\ldots . . .$. & ........... & - & ........ & ........ & .............. & $\ldots$ & $\cdots$ & .............. \\
\hline 10 & $\begin{array}{cc}\text { July } & 17 \\
17 \\
17 \\
17 \\
17 \\
17\end{array}$ & \begin{tabular}{|r|}
10.46 \\
10.59 \\
\\
\end{tabular} & \begin{tabular}{|r|}
13.98 \\
14.32 \\
\\
\end{tabular} & $\begin{array}{l}.561 \\
.691 \\
.739 \\
.826 \\
.784 \\
.848\end{array}$ & $\begin{array}{l}.095 \\
.138 \\
.135 \\
.178 \\
.151 \\
.132 \\
\end{array}$ & \begin{tabular}{|c|} 
\\
\\
\end{tabular} & $\begin{array}{l}5.28 \\
6.50 \\
6.95 \\
7.77 \\
7.37 \\
7.97 \\
\end{array}$ & \begin{tabular}{r|}
.89 \\
1.30 \\
1.27 \\
1.68 \\
1.42 \\
1.24
\end{tabular} & $\begin{array}{l}140.17 \\
138.95 \\
138.50 \\
137.68 \\
138.08 \\
137.48 \\
\end{array}$ & $\begin{array}{l}96.37 \\
95.53 \\
95.22 \\
94.66 \\
94.93 \\
94.52 \\
\end{array}$ & $\begin{array}{l}5.46 \\
5.41 \\
5.40 \\
5.37 \\
5.38 \\
5.36 \\
\end{array}$ & \begin{tabular}{|c|} 
\\
\end{tabular} \\
\hline A verage... & & 10.525 & 14.15 & .741 & .138 & 145.45 & 6.97 & 1.27 & 138.48 & 95.21 & 5.40 & 1.101 \\
\hline $11 \ldots \ldots$ & $\begin{array}{rr}\text { July } & 23 \\
& 23 \\
23\end{array}$ & $\begin{array}{l}10.73 \\
10.83\end{array}$ & $\begin{array}{l}\text { 14. } 50 \\
14.03\end{array}$ & $\begin{array}{l}.321 \\
.489 \\
.258 \\
\end{array}$ & $\begin{array}{l}.090 \\
.090 \\
.126\end{array}$ & - & $\begin{array}{l}3.25 \\
4.96 \\
2.61\end{array}$ & $\begin{array}{r}.78 \\
.78 \\
1.09\end{array}$ & $\begin{array}{l}154.88 \\
153.17 \\
155.52\end{array}$ & $\begin{array}{l}97.94 \\
96.86 \\
98.35\end{array}$ & $\begin{array}{l}3.83 \\
\text { 3. } 79 \\
3.85\end{array}$ & \begin{tabular}{|l}
$\ldots \ldots$ \\
\\
\end{tabular} \\
\hline A ver & & 10.78 & 14.265 & .356 & .101 & 158.13 & 3.61 & .88 & 154.52 & 97.72 & 3.82 & .796 \\
\hline
\end{tabular}

${ }^{1}$ Assuming the expansion of the liquids in the April 3 , the July 17 , and the 23 experiments was $0.44 \mathrm{ml} / \mathrm{dm}^{3} /{ }^{\circ}$ between 20 and $80^{\circ} \mathrm{C}$; and for all other experiments, $0.45 \mathrm{ml} / \mathrm{dm}^{3} /{ }^{\circ}$. ${ }^{2}$ Including the amount discarded in the pulp water, since this also diffused during the period. 
TABLE 9.-Gross extraction-Continued

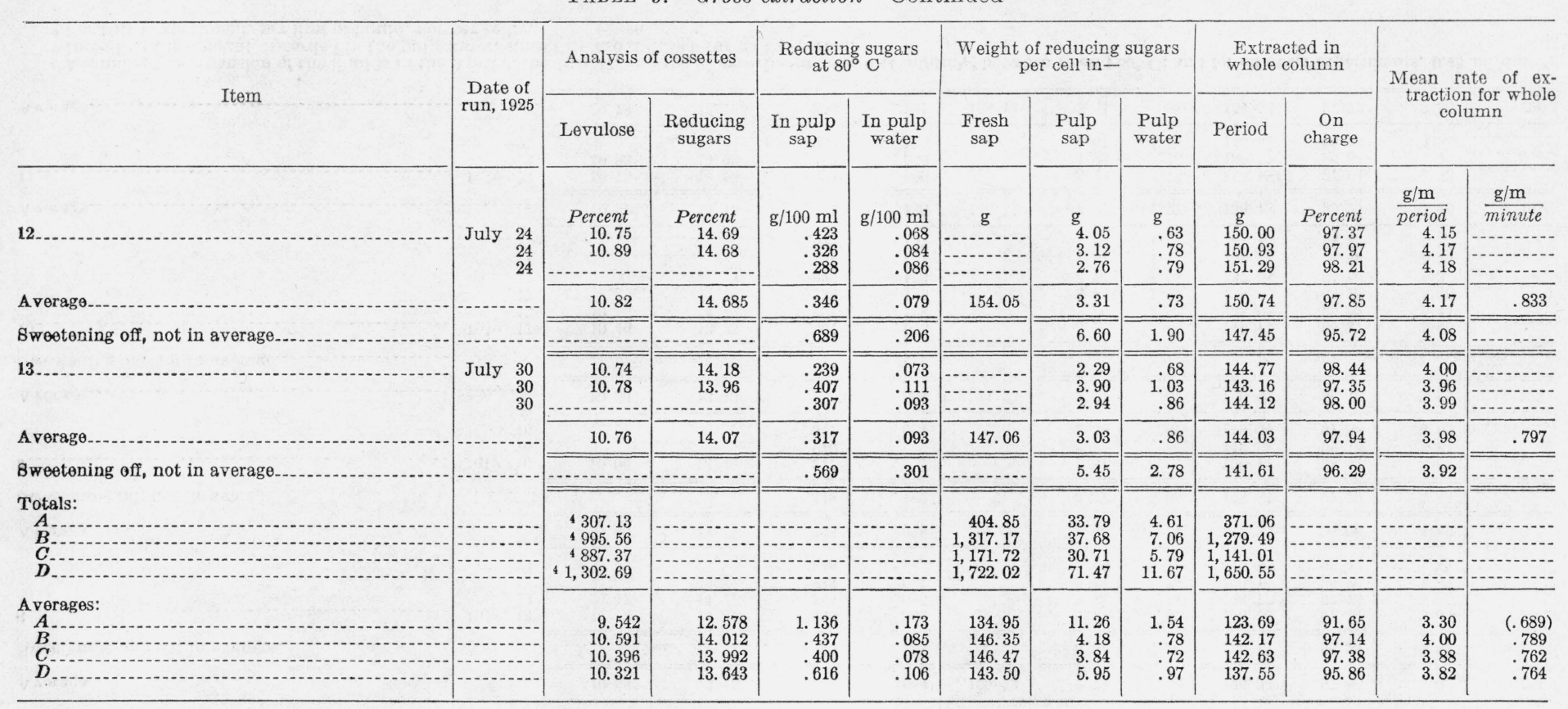

4 Grams of levulose per cell. The average quantity of levulose per 100 reducing sugar is 75.65; of reducing sugar per 100 levulose, 132.19. 
Apparently the difference in the mean gross rates of extraction was due to differences in the operating conditions produced by variation in the length of the terms of processing and in the velocities of phase translation. Thus the mean rate of extraction per minute for the eight longer columns was 69.2 percent of the mean rate attained in the column of medium length; while the mean flux velocity per minute was 69.4 percent, and the reciprocal duration of term 68.6 percent of the respective values for the column of medium length.

That the saccharides containing the greater proportions of levulose were not preferentially retarded during diffusion is indicated by the fact that the levulose ratio (stated in table 10 as parts of levulose in 100 parts of reducing sugars) was not less in the diffusion juice than in the cossettes, and not greater in the residues (of pulp and pulp water) than in the cossetes. The mean of all tests made in connection with these experiments indicates that the polysaccharides of the cossettes yielded upon hydrolysis about three-fourths levulose and one-fourth other reducing sugars. Some interesting relations among the relative proportions of levulose, other reducing sugars, and soluble substances not classified as sugars are presented in table 11.

TABLE 10.-Yield of residues and analytical data on diffusion juice

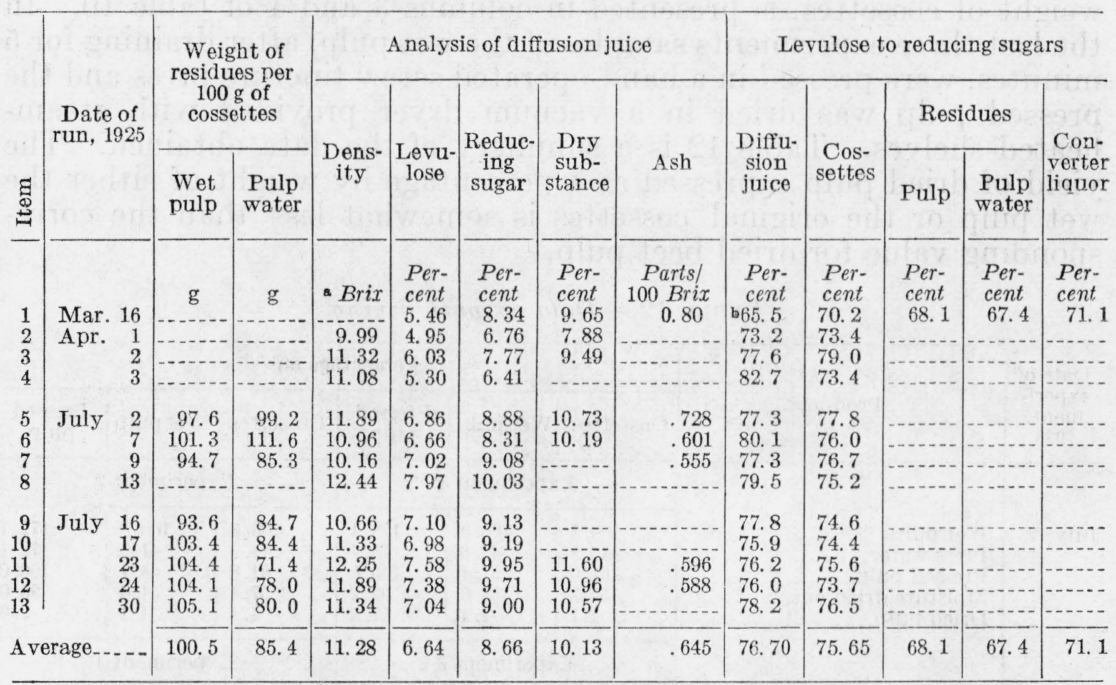

a Not corrected to indicate dry substance equivalent to levulose; and not taken on the same sample used in the estimation of dry substance.

b This result seems erroneous, since the same juice converted yielded 71.1. 
TABLE 11.-Miscellaneous ratios among levulose, reducing sugars, and dry substance in diffusion juice

\begin{tabular}{|c|c|c|c|c|c|c|}
\hline \multirow{2}{*}{ Item } & \multirow{2}{*}{$\begin{array}{c}\text { Date of } \\
\text { experiment, } \\
1925\end{array}$} & \multicolumn{2}{|c|}{$\begin{array}{l}\text { Purity quotient based } \\
\text { on- }\end{array}$} & \multicolumn{2}{|c|}{$\begin{array}{l}\text { Parts of total solids } \\
\text { containing } 100 \text { parts of- }\end{array}$} & \multirow{2}{*}{$\begin{array}{l}\text { Reducing } \\
\text { sugar } \\
\text { "excess", } \\
\text { on levulose }\end{array}$} \\
\hline & & Levulose & $\begin{array}{l}\text { Reducing } \\
\text { sugars }\end{array}$ & Levulose & $\begin{array}{l}\text { Reducing } \\
\text { sugars }\end{array}$ & \\
\hline $\begin{array}{l}1 \ldots \\
2 \ldots \\
3 \ldots\end{array}$ & \multirow[t]{2}{*}{$\begin{array}{lr}\text { March } & 16 \\
\text { April } & 1 \\
& 2\end{array}$} & $\begin{array}{l}56.6 \\
62.8 \\
63.5\end{array}$ & $\begin{array}{l}86.4 \\
85.8 \\
81.9\end{array}$ & $\begin{array}{l}177 \\
159 \\
157\end{array}$ & $\begin{array}{l}116 \\
117 \\
122\end{array}$ & $\begin{array}{l}52.8 \\
36.6 \\
28.9\end{array}$ \\
\hline Mean of 3 & & 61.0 & 84.7 & 164 & 118 & $\overline{39.4}$ \\
\hline $\begin{array}{l}5 \\
6 \\
11 \\
12 \\
13\end{array}$ & \multirow[t]{3}{*}{$\begin{array}{rr}\text { July } & 2 \\
& 7 \\
& 23 \\
24 \\
24 \\
30\end{array}$} & $\begin{array}{l}63.9 \\
65.4 \\
65.3 \\
67.3 \\
66.6 \\
\end{array}$ & $\begin{array}{l}82.8 \\
81.6 \\
85.8 \\
88.6 \\
85.1\end{array}$ & $\begin{array}{l}156 \\
153 \\
153 \\
149 \\
150\end{array}$ & $\begin{array}{l}121 \\
123 \\
117 \\
113 \\
117 \\
\end{array}$ & $\begin{array}{l}29.5 \\
24.8 \\
31.3 \\
31.6 \\
27.8\end{array}$ \\
\hline Mean of 5 & & 65.7 & 84.8 & 152 & 118 & 29.0 \\
\hline Mean of 8 & & 63.9 & a 84.75 & 156 & a 118 & 32.9 \\
\hline
\end{tabular}

a Values assumed in calculating densities, tables 7, 8, and 9.

\section{RESIDUES}

In all but one of the July experiments the pulp and pulp water were weighed as discharged. The mean relative weight of each, per hundredweight of cossettes, is presented in columns 3 and 4 of table 10 . In the last three experiments samples of the wet pulp, after draining for 5 minutes, were pressed in a hand-operated screw tincture press and the pressed pulp was dried in a vacuum dryer provided with steamheated shelves. Table 12 is a summary of the data obtained. The yield of dried pulp expressed as a percentage by weight of either the wet pulp or the original cossettes is somewhat less than the corresponding value for dried beet pulp.

TABLE 12.-Data on pulp drying

\begin{tabular}{|c|c|c|c|c|c|c|c|}
\hline \multirow{2}{*}{$\begin{array}{l}\text { Date of } \\
\text { experi- } \\
\text { ment, } \\
1925\end{array}$} & \multirow[b]{2}{*}{ Product } & \multicolumn{6}{|c|}{ Percentage on- } \\
\hline & & Cossettes & Wet pulp & $\begin{array}{l}\text { Pressed } \\
\text { pulp }\end{array}$ & Cossettes & Wet pulp & $\begin{array}{l}\text { Pressed } \\
\text { pulp }\end{array}$ \\
\hline \multirow{3}{*}{ July 23} & \multirow{3}{*}{$\begin{array}{l}\text { Wet pulp } \\
\text { Press water } \\
\text { Pressed pulp- } \\
\text { Moisture dried out. } \\
\text { Dried pulp. }\end{array}$} & \multicolumn{3}{|c|}{ Experiment 1} & \multicolumn{3}{|c|}{ Experiment 2} \\
\hline & & $\begin{array}{r}106.3 \\
45.3 \\
61.0 \\
56.3 \\
4.7\end{array}$ & $\begin{array}{r}100.0 \\
42.6 \\
57.4 \\
53.0 \\
4.4\end{array}$ & $\begin{array}{r}178.4 \\
78.4 \\
100.0 \\
92.2 \\
7.8\end{array}$ & $\begin{array}{r}106.3 \\
44.5 \\
61.8 \\
57.4 \\
4.4\end{array}$ & $\begin{array}{r}100.0 \\
41.9 \\
58.1 \\
54.0 \\
4.1\end{array}$ & $\begin{array}{r}172.1 \\
72.1 \\
100.0 \\
93.0 \\
7.0\end{array}$ \\
\hline & & & xperiment & & & xperiment & \\
\hline \multirow[t]{2}{*}{ July 24} & $\begin{array}{l}\text { Wet pulp } \\
\text { Press water } \\
\text { Pressed pulp } \\
\text { Moisture dried out. } \\
\text { Dried pulp. }\end{array}$ & $\begin{array}{r}104.6 \\
49.8 \\
54.8 \\
50.5 \\
4.3\end{array}$ & $\begin{array}{r}100.0 \\
47.6 \\
52.4 \\
48.3 \\
4.1\end{array}$ & $\begin{array}{r}190.7 \\
90.7 \\
100.0 \\
92.2 \\
7.8\end{array}$ & $\begin{array}{r}104.6 \\
39.8 \\
64.8 \\
59.7 \\
5.1\end{array}$ & $\begin{array}{r}100.0 \\
38.1 \\
61.9 \\
57.0 \\
4.9\end{array}$ & $\begin{array}{r}161.5 \\
61.5 \\
100.0 \\
92.0 \\
8.0\end{array}$ \\
\hline & & \multicolumn{6}{|c|}{ Experiment 5} \\
\hline \multirow[t]{3}{*}{ July 30} & $\begin{array}{l}\text { Wet pulp } \\
\text { Press water- } \\
\text { Pressed pulp- } \\
\text { Moisture dried out } \\
\text { Dried pulp }\end{array}$ & $\begin{array}{r}100.3 \\
55.6 \\
44.5 \\
40.4 \\
4.1\end{array}$ & $\begin{array}{r}100.0 \\
55.5 \\
44.5 \\
40.4 \\
4.1\end{array}$ & $\begin{array}{r}224.5 \\
124.5 \\
100.0 \\
90.7 \\
9.3\end{array}$ & & & $\cdots$ \\
\hline & & \multicolumn{3}{|c|}{ A verages of five experiments } & & & \\
\hline & $\begin{array}{l}\text { Wet pulp } \\
\text { Press water } \\
\text { Pressed pulp } \\
\text { Moisture dried out..... } \\
\text { Dried pulp.................. }\end{array}$ & 4.5 & $\begin{array}{r}100.0 \\
45.1 \\
54.9 \\
50.5 \\
4.3\end{array}$ & 8.0 & |-con & . & . \\
\hline
\end{tabular}




\section{SPECIAL REGIMES}

\section{EXTRACTION WITH PREHEATING}

Other conditions being equivalent, the practice of preheating the cossettes before introducing them to the flux resulted in a higher concentration of the polysaccharides in the diffusion juice and in a smaller amount of rejectment of extractives in the residues. This was true whether the juice, which was circulated for heating, was acidified or not.

\section{MIDCOLUMN DOSAGE WITH SULPHUR DIOXIDE}

In devising the regime of midcolumn dosage ${ }^{14}$ it was anticipated that certain classes of reagents might be eliminated from the residues at least as extensively as the original extractives. The results of a single experiment will serve to illustrate this effect.

(a) EXPERIMENTAL CONDITIONS

(1) Experiment of May 7, 1928.-Folded arrangement of cells in battery, with 18 cells under flux and no preheating. Charges uniform at $1.000 \mathrm{~kg}$. Saturation of flood liquid with $\mathrm{SO}_{2}$ applied during transit between postures 9 and 10 in a total volume of approximately 6.6 liters under circulation. Mean duration of retention in circulatory system, 13.3 minutes. Mean period, 4.72 minutes; mean term of retention of cossettes, 84.96 minutes. Mean temperature of material in diffusion zone and saturator, $70^{\circ} \mathrm{C}$. Mean advancement of chips, 1.18 percent of column length per minute; mean flood recession, 1.50 cell lengths/period $=1.76$ percent of column length per minute. Mean operating level of liquid in saturator, $40 \mathrm{~cm}$. Other details of the operating conditions are presented in tables 13 to 15 , inclusive.

TABLE 13.-Volumetric capacity of circulatory system ${ }^{1}$

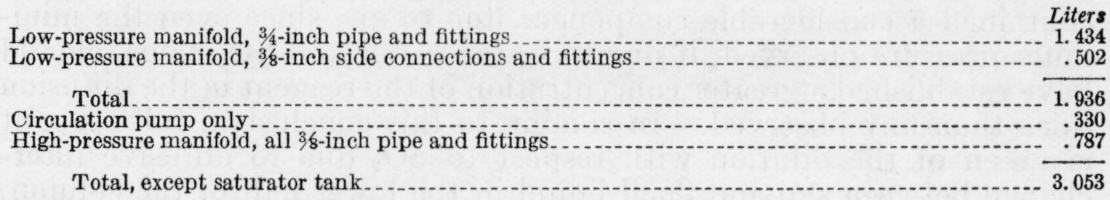

VOLUMETRIC CAPACITY OF SATURATOR TANK AT VARIOUS OPERATING LEVELS

\begin{tabular}{|c|c|c|c|c|c|}
\hline Gage & Capacity & Gage & Capacity & Gage & Capacity \\
\hline $\begin{array}{l}\text { cm } \\
10.3-1 \\
16.6 \\
19.8 \\
22.2 \\
25.0 \\
29.5\end{array}$ & $\begin{array}{r}\text { Liters } \\
\text { 1. } 70 \\
2.05 \\
2.31 \\
2.51 \\
2.74 \\
3.10\end{array}$ & $\begin{array}{l}\text { cm } \\
32.9 \\
35.4 \\
39.0 \\
44.9 \\
52.1 \\
59.7\end{array}$ & $\begin{aligned} \text { Liters } \\
\text { 3. } 24 \\
3.37 \\
3.51 \\
3.86 \\
4.10 \\
4.35\end{aligned}$ & $\begin{array}{l}\text { cm } \\
66.7-5 \\
76.5 \\
76.0 \\
80.1-7.0 \\
87.7\end{array}$ & $\begin{array}{r}\text { Liters } \\
\text { 4. } 62 \\
4.87 \\
5.08 \\
5.20 \\
5.35 \\
5.50\end{array}$ \\
\hline
\end{tabular}

1 The working capacity of the whole circulatory system could vary between the limits of 5 and 8 liters, and at the mean level employed in the experiment of May 7, 1928, its capacity was ar proximately 6.6 liters.

14 J. Research NBS 15, 452 and 1271 (1935) RP840. 
TABLE 14.-Summary of operating volumes

\begin{tabular}{|c|c|c|c|c|c|c|c|c|}
\hline \multirow[b]{2}{*}{ Item } & \multicolumn{2}{|c|}{ Sap } & \multicolumn{2}{|c|}{ Flood } & \multicolumn{2}{|c|}{ Draft } & \multicolumn{2}{|c|}{ Flux } \\
\hline & Liters & $\begin{array}{l}\text { Percent- } \\
\text { age on } \\
\text { sap }\end{array}$ & Liters & $\begin{array}{l}\text { Percent- } \\
\text { age on } \\
\text { sap }\end{array}$ & Liters & $\begin{array}{l}\text { Percent- } \\
\text { age on } \\
\text { sap }\end{array}$ & Liters & $\begin{array}{l}\text { Percent- } \\
\text { age on } \\
\text { sap }\end{array}$ \\
\hline Per cell or per period & 0.944 & 100.0 & 0.939 & 99.5 & 1.407 & 149.0 & 2.346 & 248.5 \\
\hline $\begin{array}{l}\text { Column: } \\
\text { Below circulation } \\
\text { Above circulation.--.-- }\end{array}$ & $\begin{array}{l}8.496 \\
8.496\end{array}$ & $\begin{array}{l}50.0 \\
50.0\end{array}$ & $\begin{array}{l}8.451 \\
8.451\end{array}$ & $\begin{array}{l}49.7 \\
49.7\end{array}$ & & & & 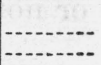 \\
\hline $\begin{array}{l}\text { Total in cells } \\
\text { In circulatory system }\end{array}$ & 16.992 & 100.0 & $\begin{array}{l}16.902 \\
6.6\end{array}$ & $\begin{array}{l}99.5 \\
38.8\end{array}$ & & & & \\
\hline In total flood column... & - n & - & 23.5 & 138.3 & 1.407 & 8. $\dot{2} 8$ & 2.346 & 13.81 \\
\hline Volume (per minute) & 0.200 & a 0.85 & & .. & 0.298 & a 1.27 & 0.497 & 2.11 \\
\hline
\end{tabular}

a These percentages are computed on the total flood column, not the sap.

The desired pressure of the gaseous contents of the saturator was maintained by immersing the liquid- $\mathrm{SO}_{2}$ cylinder in a steam-heated water-bath which was adjusted by hand to a temperature of approximately $30^{\circ} \mathrm{C}$ throughout the experiment. The pressure of the battery supply water was that produced by a small booster pump of the centrifugal type in series with the city water supply, and it averaged $54 \mathrm{lb} /$ in. $^{2}$ above atmospheric pressure. At the rate of flux employed an average head of $33 \mathrm{lb} / \mathrm{in}^{2}{ }^{2}$ was required to force the flood liquid through the upper half of the column, and the difference, $21 \mathrm{lb} / \mathrm{in}^{2}$, was the maximum mean pressure allowable for the gases in the scrubber, where the mean surface of the liquid was approximately level with the low pressure manifold. If the pressure due to air in the scrubber had been negligible, the temperature of the liquid $\mathrm{SO}_{2}$ could not have exceeded 4 to $24^{\circ}$, although the temperature of the waterbath never was less than $26^{\circ} \mathrm{C}$. Actually the pressure must have contained a considerable component due to air, since even the minimum pressure observed, if due to water vapor and $\mathrm{SO}_{2}$ alone, should have established a greater concentration of the reagent in the diffusion juice than any observed. In coming to this conclusion, full account is taken of the dilution with respect to $\mathrm{SO}_{2}$ due to diffusive interchange between sap and flood liquid in the lower half of the column. Unfortunately, no direct observations were made on the concentrations of $\mathrm{SO}_{2}$ which existed in either the liquid or the gaseous contents of the saturator. Details of the pressures observed are presented in table 15. The gaseous pressure in the scrubber was approximately equal to the hydrostatic pressure in the low-pressure manifold at the mean operating level of $40 \mathrm{~cm}$, which was maintained in the scrubber. 
TABLE 15.-Summary of pressures

\begin{tabular}{|c|c|c|c|c|c|c|c|}
\hline \multirow{3}{*}{ Time } & \multicolumn{5}{|c|}{ Gage pressures } & \multirow{3}{*}{$\begin{array}{l}\text { Temper- } \\
\text { ature of } \\
\text { water- } \\
\text { bath }\end{array}$} & \multirow{3}{*}{$\begin{array}{l}\text { Absolute } \\
\text { pressure of } \\
\text { air, water } \\
\text { vapor, and } \\
\mathrm{SO}_{2}\end{array}$} \\
\hline & \multirow{2}{*}{$\begin{array}{l}\text { Battery } \\
\text { supply } \\
\text { water }\end{array}$} & \multirow{2}{*}{$\begin{array}{l}\text { Pressure } \\
\text { drop to } \\
\text { mid- } \\
\text { column }\end{array}$} & \multicolumn{3}{|c|}{ In circulatory system } & & \\
\hline & & & $\begin{array}{l}\text { Low- } \\
\text { pressure } \\
\text { manifold }\end{array}$ & $\begin{array}{l}\text { Develop- } \\
\text { ed by cir- } \\
\text { culation } \\
\text { pump }\end{array}$ & $\begin{array}{l}\text { High- } \\
\text { pressure } \\
\text { manifold }\end{array}$ & & \\
\hline $\begin{array}{l}11: 24 \text { a. } \mathrm{m} \\
11: 45 \text { a. } \mathrm{m} \\
12: 00 \text { noon } \\
12: 05 \text { p. m }\end{array}$ & $\begin{array}{r}\mathrm{lb} / \mathrm{in} .^{2} \\
52 \\
52 \\
54 \\
52 \\
-\end{array}$ & $\begin{array}{r}\text { lb/in. } .^{2} \\
14 \\
30 \\
36 \\
28 \\
\end{array}$ & $\begin{array}{r}\text { lb/in. } \\
38 \\
22 \\
18 \\
24 \\
36\end{array}$ & $\begin{array}{r}\mathrm{lb} / \mathrm{in} .^{2} \\
8 \\
8 \\
8 \\
6 \\
8\end{array}$ & $\begin{array}{r}\text { lb/in. } \\
46 \\
30 \\
26 \\
30 \\
44\end{array}$ & $\begin{array}{r}{ }^{\circ} \mathrm{C} \\
30 \\
30 \\
26 \\
30 \\
- \\
-\end{array}$ & $\begin{array}{r}\text { atm } \\
3.59 \\
2.50 \\
2.22 \\
2.63 \\
3.45\end{array}$ \\
\hline $\begin{array}{l}12: 30 \text { p. } \mathrm{m} \\
2: 00 \text { p. } \mathrm{m} \\
\text { 3:14 p. } \mathrm{m} \\
4: 40 \text { p. } \mathrm{m}\end{array}$ & $\begin{array}{l}54 \\
48 \\
59 \\
60\end{array}$ & $\begin{array}{l}33 \\
31 \\
47 \\
47\end{array}$ & $\begin{array}{l}21 \\
17 \\
12 \\
13\end{array}$ & $\begin{array}{r}8 \\
8 \\
10 \\
8\end{array}$ & $\begin{array}{l}29 \\
25 \\
22 \\
21\end{array}$ & $\begin{array}{l}30 \\
30 \\
29 \\
-\cdots\end{array}$ & $\begin{array}{l}2.43 \\
2.16 \\
1.82 \\
1.88\end{array}$ \\
\hline Mean & 54 & 33 & 21 & 8 & 27 & 29 & 2. 37 \\
\hline
\end{tabular}

(b) EXPERIMENTAL RESULTS

The concentrations of reducing sugars and $\mathrm{SO}_{2}$ were observed in the resulting products for several of the periods. The results, as identified with the charges numbered serially from the beginning, are presented in table 16. The residues are those which resulted from the extraction of a given charge and the diffusion juice that which was drawn from the cell containing the given charge.

TABLE 16.-Observed concentrations of $\mathrm{SO}_{2}$ and reducing sugars in products

\begin{tabular}{|c|c|c|c|c|c|c|}
\hline \multirow[b]{2}{*}{ Charge } & \multicolumn{2}{|c|}{ Pulp sap } & \multicolumn{2}{|c|}{ Pulp water } & \multicolumn{2}{|c|}{ Diffusion juice } \\
\hline & $\mathrm{SO}_{2}$ & $\begin{array}{l}\text { Reducing } \\
\text { sugar }\end{array}$ & $\mathrm{SO}_{2}$ & $\begin{array}{l}\text { Reducing } \\
\text { sugar }\end{array}$ & $\mathrm{SO}_{2}$ & $\begin{array}{l}\text { Reducing } \\
\text { sugar }\end{array}$ \\
\hline 10 & $\mathrm{mg} / 100 \mathrm{ml}$ & $\mathrm{mg} / 100 \mathrm{ml}$ & $\mathrm{mg} / 100 \mathrm{ml}$ & $\mathrm{mg} / 100 \mathrm{ml}$ & $\begin{array}{c}\mathrm{mg} / 100 \mathrm{ml} \\
432.0 \\
216.2\end{array}$ & $\begin{array}{c}\mathrm{mg} / 100 \mathrm{ml} \\
4,600 \\
4,210\end{array}$ \\
\hline 1313 & $\begin{array}{l}1.16 \\
2.09 \\
2.34 \\
2.13\end{array}$ & $\begin{array}{r}80.40 \\
87.60 \\
146.00\end{array}$ & $\begin{array}{l}0.864 \\
1.660 \\
0.896 \\
1.230\end{array}$ & $\begin{array}{l}14.35 \\
37.60 \\
20.45 \\
62.37\end{array}$ & $\begin{array}{r}216.2 \\
-\end{array}$ & 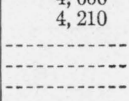 \\
\hline $21 \ldots$ & $\begin{array}{l}\text { 2. } 56 \\
4.87\end{array}$ & $\begin{array}{l}143.22 \\
127.49\end{array}$ & $\begin{array}{l}\text { 1. } 540 \\
3.170\end{array}$ & $\begin{array}{l}29.92 \\
34.50\end{array}$ & & \\
\hline 41 & & - & & & 470.9 & $4,380^{\circ}$ \\
\hline 46 & 28.60 & 320.10 & 10.150 & 34.65 & $\begin{array}{l}444.2 \\
296.2\end{array}$ & $\begin{array}{l}4,040 \\
4,710\end{array}$ \\
\hline $\begin{array}{l}\text { Total, charges } 10 \text { to } 43 \\
\text { A verage, charges } 10 \text { to } 43\end{array}$ & $\begin{array}{l}15.15 \\
2.525\end{array}$ & $\begin{array}{l}\text { 584. } 72 \\
116.944\end{array}$ & $\begin{array}{l}9.610 \\
1.602\end{array}$ & $\begin{array}{c}199.19 \\
33.198\end{array}$ & $\begin{array}{l}1,563.3 \\
\quad 390.83\end{array}$ & $\begin{array}{l}17,230 \\
4,307.5\end{array}$ \\
\hline
\end{tabular}

(c) RELATIVE EXTRACTIONS OF SULPHUR DIOXIDE

The performance of the process with respect to the removal of $\mathrm{SO}_{2}$ from the residues relative to the concurrent extraction of reducing sugars is expressed very strikingly in table 17 , which is calculated from table 16. 
TABLE 17.-Relative concentrations of extractives

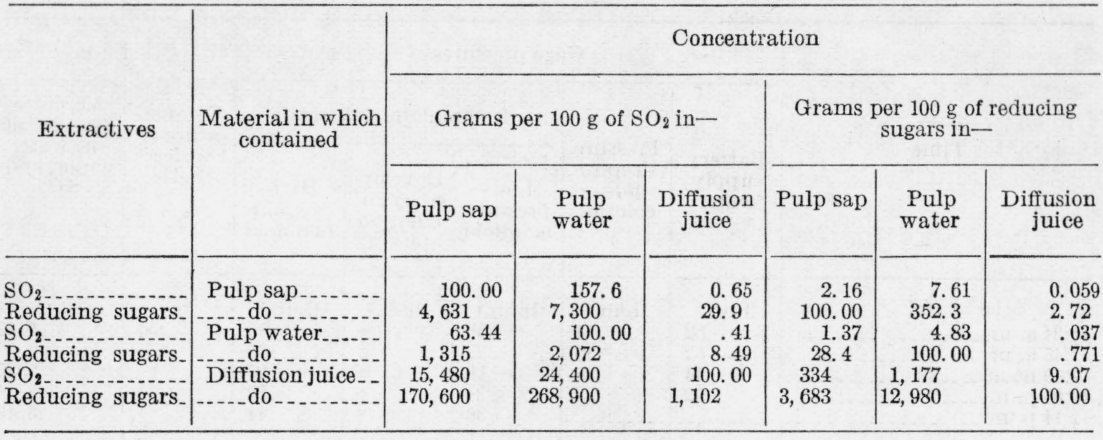

Thus for every $100 \mathrm{~g}$ of $\mathrm{SO}_{2}$ in the diffusion juice, the pulp sap contained but $0.65 \mathrm{~g}$ and the pulp water but $0.41 \mathrm{~g}$; while for every $100 \mathrm{~g}$ of reducing sugars in the diffusion juice the pulp sap contained $2.71 \mathrm{~g}$ and the pulp water $0.77 \mathrm{~g}$. The fact that the pulp sap contained relatively less than one-fourth as much $\mathrm{SO}_{2}$ as reducing sugars and the pulp water relatively more than one-half as much $\mathrm{SO}_{2}$ as reducing sugars was due to the fact that the reagent was diffusing more rapidly than the polysaccharides. The velocity of diffusion for the reagent was so much greater that the flood liquid (pulp water) in the last posture could attain a concentration of $\mathrm{SO}_{2}$, which was 63 percent of that left in the sap while it was attaining a concentration of reducing sugars which was but 28 percent of that left in the sap $(41 / 0.65=63 ; 77 / 2.71=28)$. The concentration of reagent could be reduced to 2.16 percent of the concentration of reducing sugars in the pulp sap by contact with flood liquid which thereby absorbed the reagent up to 4.83 percent of its concentration of reducing sugars. (Notice that all concentrations are expressed on a gram basis, not molecular. The molecular concentration of the polysaccharides cannot be stated, since the mean molecular weight is not known.)

TABLE 18.-Brief of relative concentrations of extractives

\begin{tabular}{|c|c|c|c|c|}
\hline Extractives & Material in which contained & $\begin{array}{l}\text { Percentage } \\
\text { on } \mathrm{SO}_{2} \text { in } \\
\text { diffusion } \\
\text { juice }\end{array}$ & $\begin{array}{l}\text { Percentage } \\
\text { on reducing } \\
\text { sugars in } \\
\text { diffusion } \\
\text { juice }\end{array}$ & $\begin{array}{l}\text { g/100 g re- } \\
\text { ducing sugars } \\
\text { in material } \\
\text { in which } \\
\text { contained }\end{array}$ \\
\hline $\mathrm{SO}_{2 \ldots}$ & $\left\{\begin{array}{l}\text { Pulp sap } \\
\text { Pulp water } \\
\text { Diffusion juice }\end{array}\right.$ & $\begin{array}{r}0.65 \\
.41 \\
100.00\end{array}$ & $\begin{array}{r}0.059 \\
.037 \\
9.073\end{array}$ & $\begin{array}{l}2.16 \\
4.83 \\
9.07\end{array}$ \\
\hline Reducing sugars & $\left\{\begin{array}{l}\text { Pulp sap } \\
\text { Pulp water } \\
\text { Diffusion juice. }\end{array}\right.$ & $\begin{array}{r}29.92 \\
8.49 \\
1,102\end{array}$ & $\begin{array}{r}2.71 \\
.77 \\
100.00\end{array}$ & $\begin{array}{l}100.00 \\
100.00 \\
100.00\end{array}$ \\
\hline
\end{tabular}

The differentials in the relative extraction of the two kinds of extractives would have been still greater except that charges $21,23,41$, 43 , and especially 46 , were discharged before the process was complete. The mechanical failure of the mass-structure of the packed cossettes had developed an excessive pressure-gradient in the upper half of the column, rendering it necessary to discard these particular charges be- 
fore they had reached the head of the column. Table 15, column 3 , indicates that this pressure-gradient had an upward trend throughout the experiment. For this reason and others it is concluded that the term of processing should have been shorter with this regime and this lot of tubers.

\section{SUMMARY}

The experimental procedure has been described for the ordinary regime of operation in the miniature diffusion battery previously described, including the method used in setting up the extraction columns and two methods used in terminating experiments. The gross performance of several columns during sweetening off has been compared with the previous performance during regular operation. The concentration gradients observed along the columns in three early experiments have been presented for future analysis. Data have been presented on the relative volumes of sap and flood liquid, the rates of phase translation, the temperatures of the flood liquid, the degree of extraction attained, and the relative magnitudes of the residues obtained in the extraction of polysaccharides from jerusalem. artichoke cossettes prepared with commercial beet knives. This includes the yield of dried pulp in three experiments. The over-all rates of the gross extraction have been correlated with the rates of phase translation employed. Finally, the relative degree of extraction of the polysaccharides and an added reagent $\left(\mathrm{SO}_{2}\right)$ has been illustrated by means of the data obtained in a single experiment with the regime of midcolumn dosage previously described by one of us.

WASHINGTON, July 23, 1937. 